\title{
Review of High-Temperature Recovery of Rare Earth (Nd/Dy) from Magnet Waste
}

\author{
Muhamad Firdaus $^{1} \cdot$ M. Akbar Rhamdhani ${ }^{1} \cdot$ Yvonne Durandet $^{1}$. \\ W. John Rankin ${ }^{2} \cdot$ Kathie McGregor ${ }^{2}$
}

Published online: 14 March 2016

(C) The Minerals, Metals \& Materials Society (TMS) 2016

\begin{abstract}
Rare-earth metals, particularly neodymium, dysprosium, and praseodymium are becoming increasingly important in the transition to a green economy due to their essential role in permanent magnet applications such as in electric motors and generators. With the increasingly limited rare-earth supply and complexity of processing $\mathrm{Nd}$, Dy, and Pr from primary ores, recycling of rare-earth based magnets has become a necessary option to manage supply and demand. Depending on the form of the starting material (sludge or scrap), there are different routes that can be used to recover neodymium from secondary sources, ranging from hydrometallurgical (based on its primary production process), electrochemical to pyrometallurgical. Pyrometallurgical routes provide solution in cases where water is scarce and generation of waste is to be limited. This paper presents a systematic review of previous studies on the high-temperature (pyrometallurgical) recovery of rare earths from magnets. The features and conditions at which the recycling processes had been studied are mapped and evaluated technically. The review also highlights the reaction mechanisms, behaviors of the rare-earth elements, and the formation of intermediate compounds in high-temperature recycling processes. Recommendations for further scientific research to enable the development of recovery of the rare-earth and magnet recycling are also presented.
\end{abstract}

The contributing editor for this article was Veena Sahajwalla.

M. Akbar Rhamdhani

ARhamdhani@swin.edu.au

1 Department of Mechanical and Product Design, Swinburne University of Technology, Melbourne, VIC 3122, Australia

2 CSIRO Mineral Resources, Bayview Avenue, Clayton, VIC 3168, Australia
Keywords Spent magnet recycling - High temperature · Rare earth · Pyrometallurgy

$\begin{array}{ll}\text { Abbreviations } \\ \text { CEMS } & \text { Conversion electron Mössbauer spectroscopy } \\ \text { CVT } & \text { Chemical vapor transport } \\ \text { EDS } & \text { Energy-dispersive X-ray spectroscopy } \\ \text { EoL } & \text { End-of-life } \\ \text { EOZ } & \text { External oxidation zone } \\ \text { HDD } & \text { Hard disk drive } \\ \text { IOZ } & \text { Internal oxidation zone } \\ \text { LME } & \text { Liquid metal extraction } \\ \text { RE } & \text { Rare earth } \\ \text { RECl } & \text { Rare-earth chloride } \\ \text { REE } & \text { Rare-earth elements } \\ \text { REO } & \text { Rare-earth oxide } \\ \text { REPM } & \text { Rare-earth permanent magnet } \\ \text { TGA } & \text { Thermogravimetric analysis } \\ \text { TMS } & \text { Transmission spectroscopy } \\ \text { WEEE } & \text { Waste electronics and electrical equipment } \\ \text { VCM } & \text { Voice coil motor }\end{array}$

\section{Introduction}

There is a great interest in rare-earth (RE) recycling due to the increasing demand for REs and the complexity of processing REs from primary ores. Recycling can potentially reduce dependence on virgin production while altering the geographic distribution of RE element (REE) supply. Rare-earth permanent magnets (REPM) accounted for $26.3 \%$ of worldwide consumption of RE in 2008, and most of the current stock of redundant material is present in 
electronic goods such as loudspeakers, mobile phones, and hard disk drives [1]. The main potential sources of REPMs for recycling are residues generated at the final finishing stage of manufacturing process (referred to as swarf); small magnets in end-of-life (EoL) consumer products; and large magnets in hybrid and electric vehicles and in wind turbines.

EoL consumer products in the form of computer hard disk drives (HDDs) are probably the most important source of REE scrap. HDDs are the single largest user of NdFeB in electronic goods with around 600 million pieces manufactured annually. With $10-20 \mathrm{~g}$ of $\mathrm{NdFeB}$ in each HDD, this equates to 6000-12,000 tons of neodymium-ironboron alloy. HDDs are not only easy to identify, but are also often routinely removed from waste electronics and electrical equipment (WEEE) and have a rapid turnover ( $\sim 5$ years) [2]. They contain several permanent magnets inside the chassis. The dominant magnets are the permanent magnets of the voice coil motor (VCM) which usually comprise two identical kidney-shaped magnets attached to a metal plate. Other magnets are built into the read/write head and the spindle motor. These are often left out in recycling as they are too small (read/write head) or too difficult to extract (spindle motor magnet).

Generally, metal recycling relies on the application of common metallurgical processes. However, due to the complex design and amount of elements in the REPM waste, adaptations of the available techniques and innovation are required. Numerous papers and conference proceedings have been published on technologies for recovering REs from REPM, and there are several general reviews of the state-of-the-art technologies [1-5], including the potential, challenges, and possible solutions associated with the recycling of the REs [6-8]. This paper presents a systematic overview of the high-temperature recycling methodologies for recovery of RE from REPM, and focuses on the scientific (such as the mechanism) and the technical aspects of the material recovery process.

\section{REPM's Composition, Microstructure, and Coercivity}

Table 1 lists typical chemical compositions of REPM waste. All REPM contain neodymium (Nd), with sometimes small amount of terbium ( $\mathrm{Tb}$ ), or dysprosium (Dy) which introduced when necessary to increase its operating temperature. Praseodymium $(\mathrm{Pr})$ is generally added to replace neodymium at a lower cost. $\mathrm{Nd}, \mathrm{Tb}, \mathrm{Dy}$, and $\mathrm{Pr}$ are all considered critical metals according to the US Department of Energy and the UN International Resource Panel. A Ni-Cu-Ni layered coating is usually applied to commercial magnets and is usually mechanically removed from most REPM waste. Al coating is mostly found in

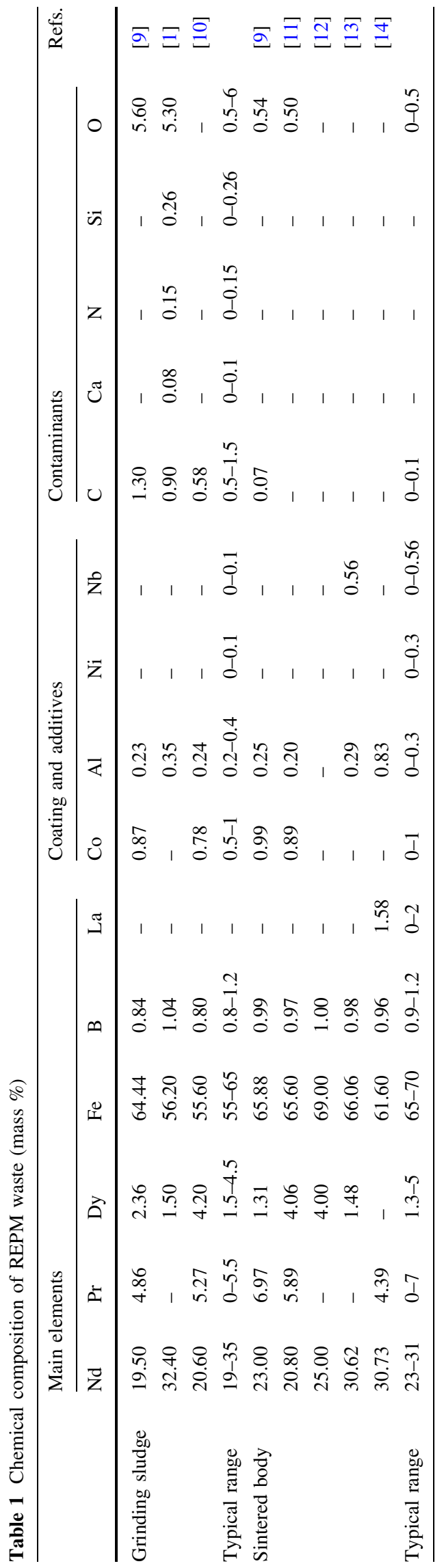


magnets from HDDs wastes along with traces of gold and silver. The main elements in the $\mathrm{Nd}-\mathrm{Fe}-\mathrm{B}$ alloy usually contain contaminants, particularly carbon and oxygen. Carbon can affect the coercivity and microstructure of finegrained Nd-Fe-B sintered magnets [15]. The main sources of carbon contamination according to Asabe et al. [9] are: carbides from REPM alloy magnets; carbon powders from the carbon plate when cut together with the magnets; powders of the whetstone consisting of the diamond and resin binder; and grinding oil.

Nd-based REPMs demonstrate a strong hard-magnetic behavior as it has bulk remanent magnetization, coercivity, and maximum energy product in the range of 1.0-1.4 T, 9.5-25 kOe, and 25-55 MGOe, respectively. The Nd-Fe-B system is characterized by two ternary compounds: $\mathrm{Nd}_{2}$ $\mathrm{Fe}_{14} \mathrm{~B}$ (typically around $85 \%$ and also called the $\phi$ phase) and $\mathrm{Nd}_{1+\varepsilon} \mathrm{Fe}_{4} \mathrm{~B}_{4}$ (typically around 2-3\%, called the $\eta$ phase or the boride phase), and a Nd-rich grain boundary phase (typically $12-13 \%$ of the material). Figure 1 shows the microstructure of commercial Nd-based magnets. Due to the peritectic system (Fig. 2), Nd-Fe-B cast alloys usually have compositions richer in $\mathrm{Nd}$ than $\mathrm{Nd}_{2} \mathrm{Fe}_{14} \mathrm{~B}$,
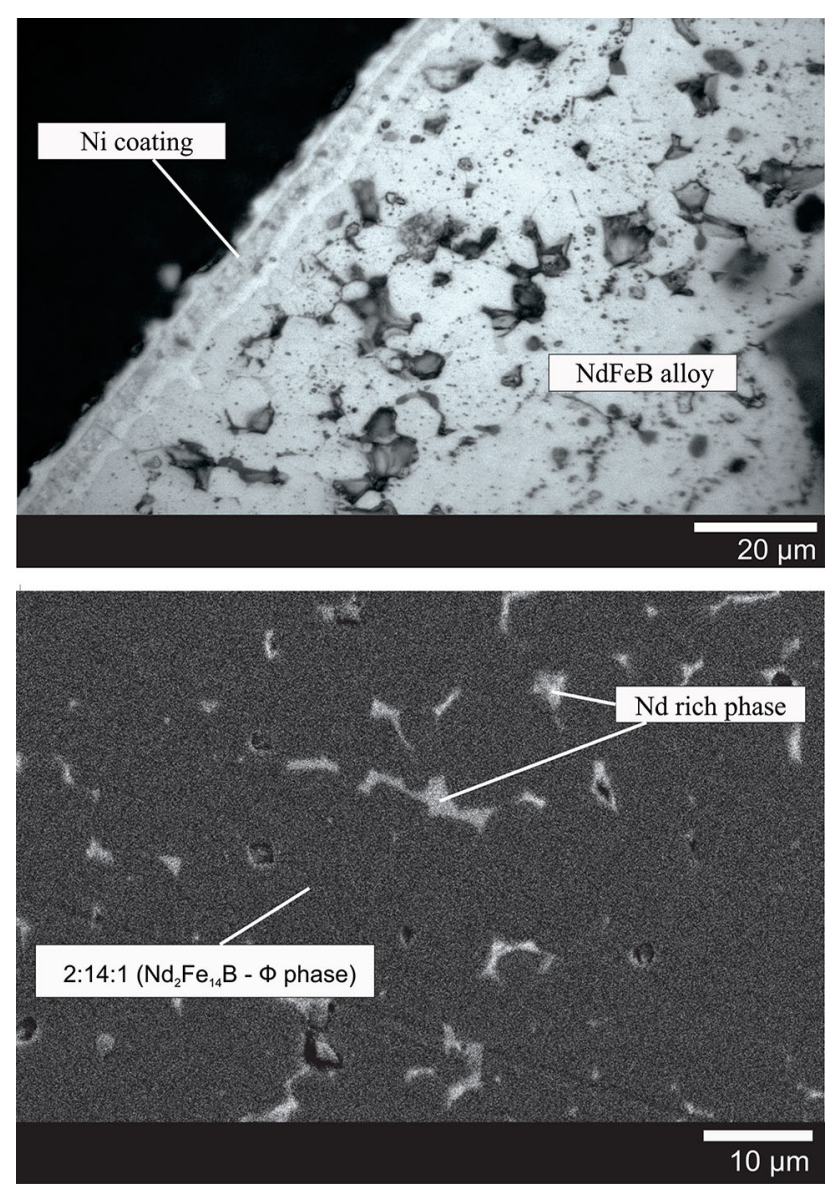

Fig. 1 Microstructure of $\mathrm{Nd}_{15} \mathrm{Fe}_{77} \mathrm{~B}_{8}$ using light microscope (top) and SEM back-scattered electron image (bottom) close to $\mathrm{Nd}_{2.6} \mathrm{Fe}_{13} \mathrm{~B}_{1.4}$, or $\mathrm{Nd}_{15} \mathrm{Fe}_{77} \mathrm{~B}_{8}$ as more commonly expressed.

The origin of the coercivity in rare-earth-transitionmetal permanent magnets is their high easy-axis magnetocrystalline anisotropy. It is strongly related to the interfacial microstructure between the main phase ( $\phi$ phase) and grain boundary phase, with magnetization reversal being the result of the nucleation and growth of reverse magnetic domains $[17,18]$. In the case of Nd-Fe-B alloy, the easy axis of magnetization is the c-axis of the complex tetragonal structure of the magnetically hard phase $\mathrm{Nd}_{2}$ $\mathrm{Fe}_{14} \mathrm{~B}$. In the presence of an external magnetizing field, it aligns along the c-axis, becoming capable of being fully magnetized to saturation with a very high coercivity [18]. The crystal structure of $\mathrm{Nd}_{2} \mathrm{Fe}_{14} \mathrm{~B}$ is relatively complex, and there are 68 atoms in the unit cell. The tetragonal structure belongs to the space group $P 4_{2} / \mathrm{mnm}$; it comprises six crystallographically inequivalent $\mathrm{Fe}$ sites and two crystallographically inequivalent $\mathrm{Nd}$ sites [18]. The homogeneity range of $\mathrm{Nd}_{2} \mathrm{Fe}_{14} \mathrm{~B}$ is very small, or even absent; it is effectively a line compound.

\section{REPM Recycling Strategies and Pyrometallurgical Routes}

Depending on the stage at which the recycled or EoL products come into the material flow, recycling can be based on any of the following strategies:

(1) material recycling, in which scrap materials are charged into smelting processes as raw materials; alloy recycling, in which the materials are regenerated into master alloys for magnet production; and magnet recycling, in which magnet alloys are reused in their current form.

All these strategies are illustrated in Fig. 3. It can be seen from Fig. 3 that strategy (3) is the shortest route in recycling, as the most obvious approach to recycling of REPM would be to reuse the magnets in their current form/ shape. This option is possible only if the magnets can be traced and collected as soon as they go into the waste to prevent contamination. Physical/mechanical separation technologies are mainly applied for separating REPM from other waste in strategy (3), and also to support strategies (1) and (2). Common hydrometallurgical processes, similar to those used in primary production, usually constitute the longest cycle in strategy (1) while pyrometallurgical processes are more flexible and can be applied in strategy (2).

Pyrometallurgical (high temperature) routes have been developed as an alternative to hydrometallurgical routes. The main disadvantages of hydrometallurgical routes are, first, the large amounts of chemicals and water required, and second, the fact that they require many steps, 
Fig. 2 Phase equilibrium of $\mathrm{Fe}-\mathrm{Nd}$ system [16]

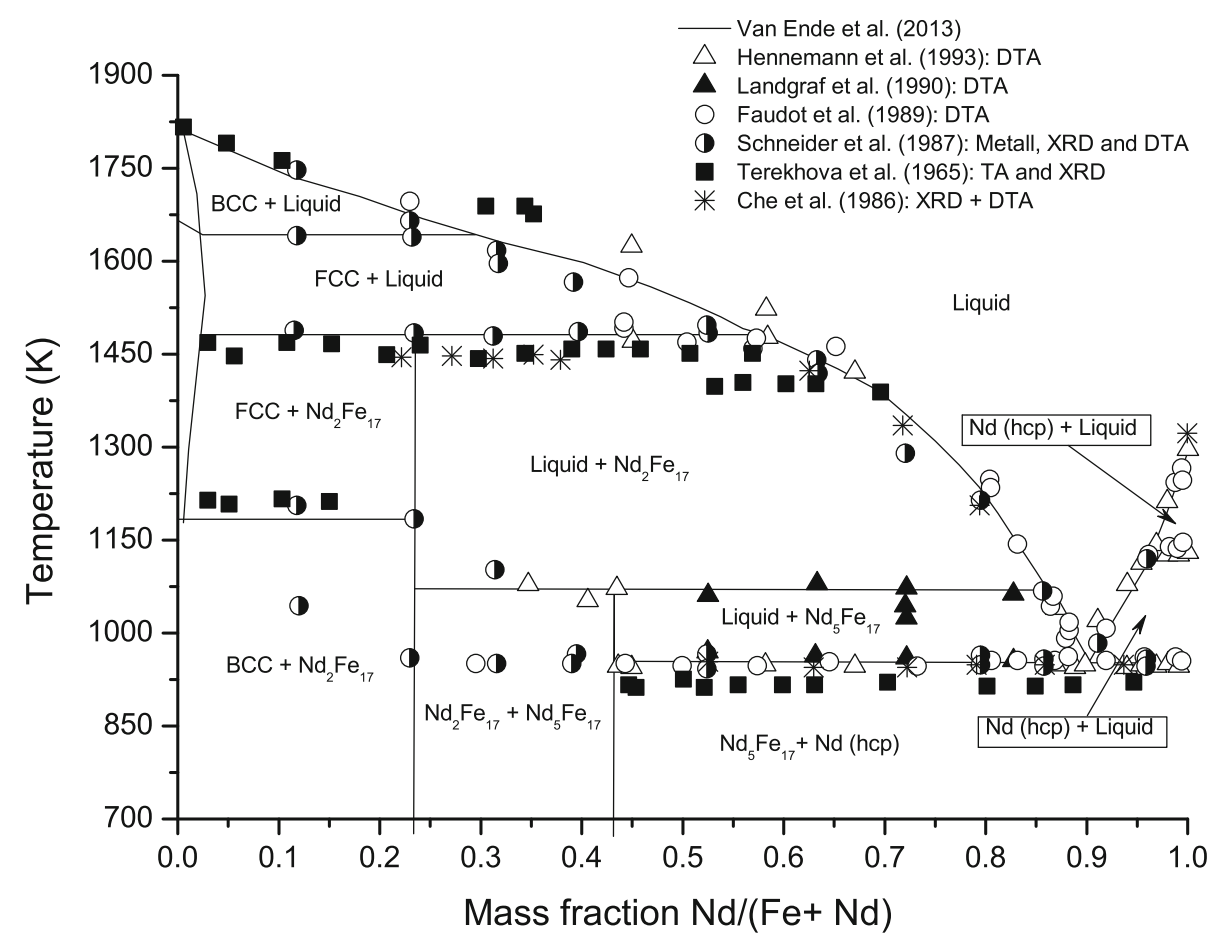

Fig. 3 Improved recycling flow sheet for REPM from Binnemans et al. [2] and Takeda et al. [3]

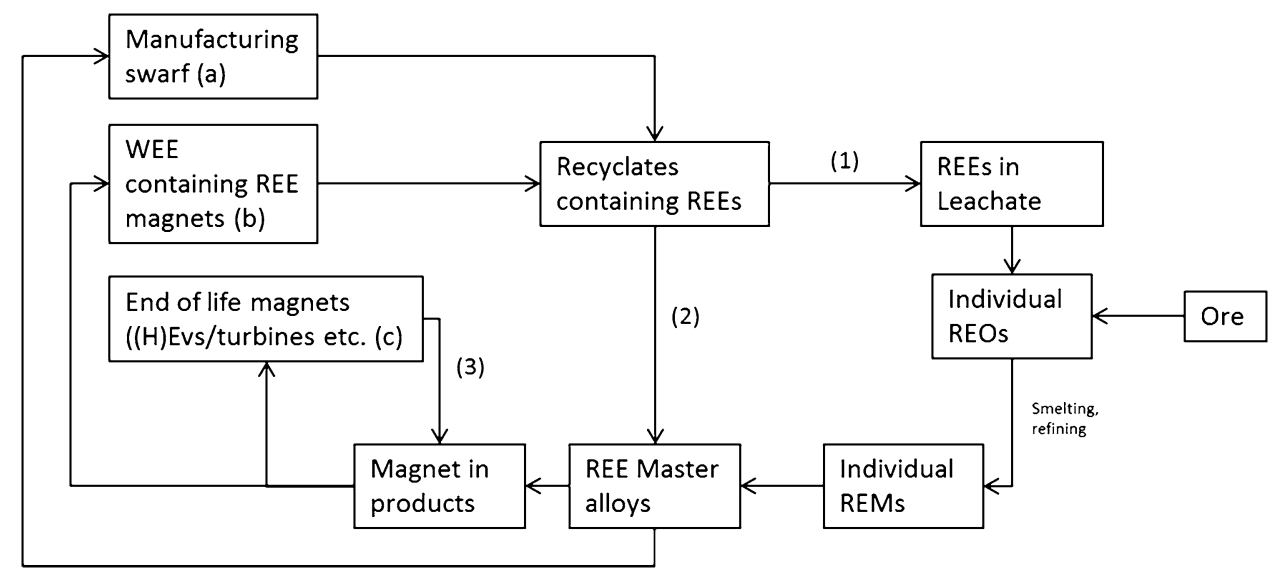

considerable energy, and relatively longer overall processing times. Much waste water is generated, and not only RE metals but also iron are dissolved by acid solution. $\mathrm{Fe}$ and $\mathrm{B}$ residues are often considered as industrial wastes, since the recycling cost of $\mathrm{Fe}$ does not meet the market price and $\mathrm{B}$ is a poisonous element that needs to be controlled environmentally. Pyrometallurgical routes provide a solution in cases where water is considered as a scarce resource and generation of waste is to be limited. Some pyrometallurgical routes also allow remelting of REE alloys or extraction of the REEs from transition metals in the metallic state; other routes can be used for recycling of partly oxidized REE magnet alloys.
Fundamental research on the thermodynamic behavior of REPM materials and on the chemical reactions between the magnet materials and the solvent medium is critical to understand and improve the RE recycling process. The thermodynamic properties of RE metal systems at high temperatures cannot be readily evaluated via traditional methods due to the chemical affinity of RE metals with oxygen or other elements [19]. The thermodynamics of the $\mathrm{Nd}-\mathrm{Fe}-\mathrm{B}$ system have been studied to understand the behavior of the alloy during high-temperature process, and have recently been applied for pyrometallurgical recycling purposes. Most authors used the work of Hallemans et al. [20] for their thermodynamic evaluation of the $\mathrm{Nd}-\mathrm{Fe}-\mathrm{B}$ 
system. Van Ende and Jung [16] recently reviewed and optimized the system. The pseudo-binary system, in which $\mathrm{B}$ is held constant, is usually applied when dealing with recycling process, which implies the importance of understanding the $\mathrm{Fe}-\mathrm{Nd}$ system. Thermodynamic information on intermetallic compounds in Nd-Fe binary system especially at high temperature is very limited. The $\mathrm{Fe}-$ $\mathrm{Nd}$ system has been reviewed by Zhang et al. [21], Okamoto [22], Marazza et al. [23] and Nagai et al. [19] and optimized by Van Ende and Jung [16]. The database for the thermodynamic evaluation was developed by Franke and Neuschütz [24] for Scientific Group Thermodata Europe (SGTE) in 2008. Figure 2 shows the optimized $\mathrm{Fe}-\mathrm{Nd}$ phase diagram [16]. Thermodynamic data for other REEs such as Dy and Pr in magnetic alloys are much more limited. Nagai et al. [25] recently evaluated data for the Dy + Fe system required for the design of recycling processes for Dy recovery. Not only the alloying elements but the thermodynamic behaviors of coating elements ( $\mathrm{Al}, \mathrm{Co}$, $\mathrm{Ni}$ and $\mathrm{Cu}$ ) with $\mathrm{Nd}$ are also important to increase the extraction yield of $\mathrm{Nd}$. Hussain et al. [26] provided critical reviews of the $\mathrm{Co}-\mathrm{Nd}, \mathrm{Cu}-\mathrm{Nd}$, and $\mathrm{Nd}-\mathrm{Ni}$ systems, while Feng et al. [27] investigated experimentally the $\mathrm{Al}-\mathrm{Fe}-\mathrm{Nd}$ system at $773 \mathrm{~K}$.

Figure 4, Tables 2 and 3 summarize the current status of research in pyrometallurgical recycling. Figure 4 classifies recycling processes into two types. Extraction type processes, in which pure RE metals are recovered by extracting REEs from wastes, are indicated using straight lines. Refining type processes, in which alloys containing $\mathrm{RE}$ are regenerated by removing harmful elements from $\mathrm{RE}$ wastes, are indicated by dashed lines. Both have advantages and disadvantages depending on the type of waste used as feed material (i.e., its contamination level) and the targeted product (pure metal which can be used for other application or magnetic alloy). Table 2 summarizes in more detail the process conditions, the reagents, and the products of various high-temperature recycling routes of REPM. As described by Takeda et al. [28], the extraction type recycling is suitable for waste heavily contaminated with oxygen, such as swarf generated in cutting process. The advantages are that pure RE metal can be obtained by separation of REEs from the waste, and heavily concentrated impurities can be removed. On the other hand, the disadvantages include long processing time, high energy requirements, high environmental burden, and limited locations for processing. Refining type recycling is suitable for a mildly contaminated waste such as used (EOL) magnets. Its advantages include shorter processing time, less energy consumption, and unlimited locations for processing. However, precise control of the composition of the regenerated alloy is difficult when various wastes are mixed. Table 3 provides a more detailed information on the advantages and disadvantages of the various processes in terms of their RE recovery rates, recyclability of the chemicals used, and process parameters.

In the extraction type of recycling, REs are extracted in the form of oxide, halide, fluoride or other metallic compound which can then be reduced to metallic form. These intermediate compounds are important as they can also be used as an extractant (e.g., RE-fluoride in recycling via flux) or as an intermediate product to accommodate the extraction process (e.g., RE-oxide in recycling via glass slag or RE chloride in CVT process). The mechanism, kinetics, and control of formation of these intermediate compounds are emerging topics in REPM pyrometallurgical recycling process development. Refining type processes, such as hydrogen decrepitation (HD), have advantages in terms of their applicability (simple and low energy requirement). However, the product quality is inferior as the processes downgrade the magnetic properties of the magnets. The benefit of the refining type process
Fig. 4 High-temperature recycling process routes for REPM (see details and references for each numbered process route in Table 1); the arrow types indicate different recycling types: extraction (straight) and refining (dashed)

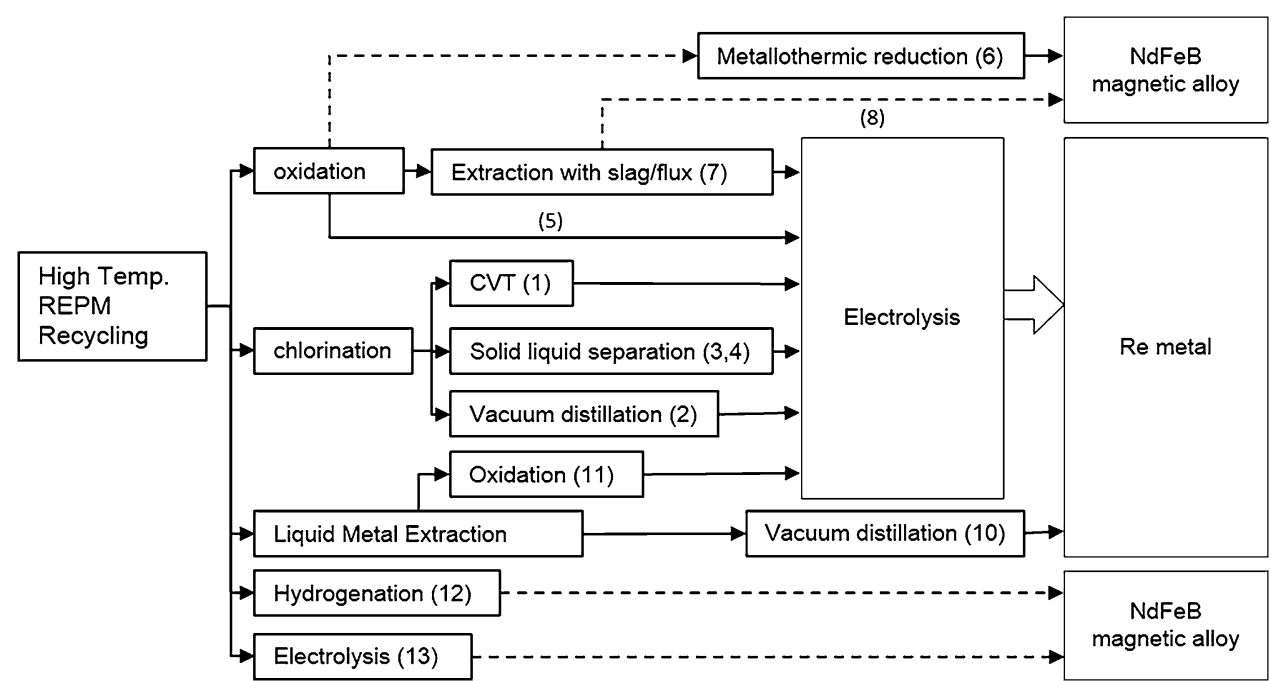


Table 2 Process conditions, reagents used, and products in different recycling routes for rare-earth permanent magnets

\begin{tabular}{|c|c|c|c|c|c|c|c|}
\hline No. & $\begin{array}{l}\text { Source } \\
\text { material }\end{array}$ & $\begin{array}{l}\text { Phase } \\
\text { system }\end{array}$ & Steps & Experimental condt. & Reagents & RE products & Refs. \\
\hline 1 & $\begin{array}{l}\text { Swarf/ } \\
\text { sludge }\end{array}$ & $\begin{array}{l}\text { Gas- } \\
\text { solid }\end{array}$ & $\begin{array}{l}\text { Chemical vapor } \\
\text { transport: } \\
\text { (1) Chlorination } \\
\text { (2) Sublimation }\end{array}$ & $1273 \mathrm{~K}, 6-82 \mathrm{~h}$ & $\mathrm{AlCl}_{3}, \mathrm{Cl}_{2}$ & $\begin{array}{l}\mathrm{NdAl}_{4} \mathrm{Cl}_{15} \\
\text { vapor } \\
\text { complexes }\end{array}$ & {$[29,30]$} \\
\hline 2 & $\begin{array}{l}\text { Swarf/ } \\
\text { sludge }\end{array}$ & $\begin{array}{l}\text { Liquid- } \\
\text { solid }\end{array}$ & $\begin{array}{l}\text { (1) Chlorination } \\
\text { (2) Vacuum distillation } \\
\text { (3) Pyrohydrolysis }\end{array}$ & $\begin{array}{l}\text { (1) } 1073 \mathrm{~K}, 12 \mathrm{~h} \\
\text { (2) } 1273 \mathrm{~K}, 3 \mathrm{~h}\end{array}$ & $\mathrm{FeCl}_{2}$ & $\mathrm{Nd}_{2} \mathrm{O}_{3}$ & {$[31,32]$} \\
\hline 3 & $\begin{array}{l}\text { Solid } \\
\text { scrap }\end{array}$ & $\begin{array}{l}\text { Liquid- } \\
\text { solid }\end{array}$ & $\begin{array}{l}\text { Selective } \\
\text { extraction }+ \text { vacuum } \\
\text { distillation }\end{array}$ & $1273 \mathrm{~K}, 12 \mathrm{~h}$ & $\mathrm{MgCl}_{2}$ & $\mathrm{NdCl}_{3}$ & [33] \\
\hline 4 & $\begin{array}{l}\text { Solid } \\
\text { scrap }\end{array}$ & $\begin{array}{l}\text { Liquid- } \\
\text { solid }\end{array}$ & Selective extraction & $523-623 \mathrm{~K}, 3-12 \mathrm{~h}$ & $\mathrm{NH}_{4} \mathrm{Cl}$ & $\mathrm{NdCl}_{3}$ & [34] \\
\hline 5 & $\begin{array}{l}\text { Swarf/ } \\
\text { sludge }\end{array}$ & $\begin{array}{l}\text { Solid- } \\
\text { liquid }\end{array}$ & $\begin{array}{l}\text { (1) Oxidation } \\
\text { (2) Melting }\end{array}$ & $1573-1823 \mathrm{~K}, 1-16 \mathrm{~h}$ & $\mathrm{C}, \mathrm{O}_{2}, \mathrm{Ar}$ & $\begin{array}{l}\text { Nd metal, } \\
\mathrm{Nd}_{2} \mathrm{O}_{3}\end{array}$ & [11] \\
\hline 6 & $\begin{array}{l}\text { Swarf/ } \\
\text { sludge }\end{array}$ & $\begin{array}{l}\text { Gas- } \\
\text { solid }\end{array}$ & $\begin{array}{l}\text { (1) Decarburation } \\
\text { (2) Heating in } \mathrm{H} 2 \\
\text { (3) Calciothermic } \\
\text { reduction }\end{array}$ & $\begin{array}{l}\text { (1) } 1073 \mathrm{~K}, 1 \mathrm{~h} \\
\text { (2) } 1253 \mathrm{~K}, 8 \mathrm{~h} \\
\text { (3) } 1223-1273 \mathrm{~K}, 3 \mathrm{~h}\end{array}$ & $\mathrm{O}_{2}, \mathrm{H}_{2}, \mathrm{Ca}$ & $\mathrm{NdFeB}$ alloy & {$[10,35-37]$} \\
\hline 7 & $\begin{array}{l}\text { Solid } \\
\text { scrap }\end{array}$ & $\begin{array}{r}\text { Liquid- } \\
\text { liquid }\end{array}$ & $\begin{array}{l}\text { (1) Oxidation } \\
\text { (2) Extraction }\end{array}$ & $1650 \mathrm{~K}$ & $\mathrm{~B}_{2} \mathrm{O}_{3}$ & $\mathrm{Nd}_{2} \mathrm{O}_{3}-\mathrm{B}_{2} \mathrm{O}_{3}$ & [38] \\
\hline 8 & $\begin{array}{l}\text { Solid } \\
\text { scrap }\end{array}$ & $\begin{array}{l}\text { Liquid- } \\
\text { liquid }\end{array}$ & Flux process & $1503 \mathrm{~K}, 12-78 \mathrm{~h}$ & $\mathrm{LiF}-\mathrm{NdF}_{3}$ & $\mathrm{NdFeB}$ alloy & [28] \\
\hline 9 & $\begin{array}{l}\text { Solid } \\
\text { scrap }\end{array}$ & $\begin{array}{l}\text { Gas- } \\
\text { solid }\end{array}$ & $\begin{array}{l}\text { (1) Oxidation } \\
\text { (2) Hydrogenation } \\
\text { (3) Carbonylation }\end{array}$ & $\begin{array}{l}\text { (1) } 523-573 \mathrm{~K}, 6 \mathrm{~h} \\
\text { (2) } 873 \mathrm{k}, 4 \mathrm{~h} \\
\text { (3) } 473 \mathrm{~K}, 24 \mathrm{~h}\end{array}$ & $\mathrm{CO}, \mathrm{S}$ (catalyst), $\mathrm{H}_{2}$ & Nd compounds & [39] \\
\hline 10 & $\begin{array}{l}\text { Solid } \\
\text { scrap }\end{array}$ & $\begin{array}{l}\text { Liquid- } \\
\text { solid }\end{array}$ & $\begin{array}{l}\text { (1) Liquid metal } \\
\text { extraction } \\
\text { (2) Vacuum distillation }\end{array}$ & $1299 \mathrm{~K}, 24-74 \mathrm{~h}$ & $\mathrm{Mg}$ & $\mathrm{Nd}$ metal & {$[40-43]$} \\
\hline 11 & $\begin{array}{l}\text { Solid } \\
\text { scrap }\end{array}$ & $\begin{array}{l}\text { Liquid- } \\
\text { solid }\end{array}$ & $\begin{array}{l}\text { (1) Liquid metal } \\
\text { extraction } \\
\text { (2) Oxidation in air }\end{array}$ & $1273-1573 \mathrm{~K}, 4-74 \mathrm{~h}$ & $\mathrm{Ag}$ & $\mathrm{Nd}_{2} \mathrm{O}_{3}$ & [44] \\
\hline 12 & $\begin{array}{l}\text { Solid } \\
\text { scrap }\end{array}$ & $\begin{array}{l}\text { Gas- } \\
\text { solid }\end{array}$ & $\begin{array}{l}\text { Hydrogen decrepitation } \\
\text { (1) Hydrogenation } \\
\text { (2) Vacuum desorption }\end{array}$ & $\begin{array}{l}\text { (1) } 298-723 \mathrm{~K} \text { (hydrogen } \\
\text { introduced step by step) } \\
\text { (2) } 973-1273 \mathrm{~K}\end{array}$ & $\mathrm{H}_{2}$ & $\begin{array}{l}\mathrm{NdFeB} \mathrm{HD} \\
\text { powder }\end{array}$ & {$[14,45-50]$} \\
\hline 13 & $\begin{array}{l}\text { Solid } \\
\text { scrap }\end{array}$ & $\begin{array}{l}\text { Liquid- } \\
\text { solid }\end{array}$ & Pyrolysis & $553 \mathrm{~K}, 1-2 \mathrm{~h}$ & $\begin{array}{l}1,2,3,4- \\
\text { Tetrahydronaphtaline }\end{array}$ & $\begin{array}{l}\text { NdFeB melt } \\
\text { spun powder }\end{array}$ & [51] \\
\hline 14 & $\begin{array}{l}\text { Solid } \\
\text { scrap }\end{array}$ & $\begin{array}{l}\text { Liquid- } \\
\text { solid }\end{array}$ & Electrolysis & $1123 \mathrm{~K}, 12 \mathrm{~h}$ & $\mathrm{LiF}-\mathrm{CaF}_{2}-\mathrm{NdF}_{3}$ & $\mathrm{Nd}-\mathrm{Ni}$ alloy & {$[52-54]$} \\
\hline
\end{tabular}

is that it extends the life of magnets, although the degree of the reduction in magnetic properties needs to be considered.

Figure 5 presents the map of temperatures and total processing times investigated by various researchers. It shows that most processes that involve the formation of oxides were investigated at higher temperatures, due mainly to the high-temperature requirement to melt the slag formed. Recycling via chlorination has been studied over a wider temperature range, but maximum recovery was reported at the higher temperatures. As summarized in Table 2, heterogeneous reactions are used to form compounds (extraction type) or remove contaminants (refining type). Differences in partial pressures, volatility, and solubility are exploited to separate the RE from other elements in the waste. 
Table 3 Advantages and disadvantages of different pyrometallurgical recycling routes for rare-earth permanent magnets

\begin{tabular}{|c|c|c|c|c|c|c|}
\hline No. & $\begin{array}{l}\text { Phase } \\
\text { system }\end{array}$ & RE products & $\begin{array}{l}\text { Further } \\
\text { processing }\end{array}$ & Advantage & Disadvantage & Refs. \\
\hline 1 & $\begin{array}{l}\text { Gas- } \\
\text { solid }\end{array}$ & $\begin{array}{l}\mathrm{NdAl}_{4} \mathrm{Cl}_{15} \\
\text { vapor } \\
\text { complexes }\end{array}$ & $\begin{array}{l}\text { Metallothermic } \\
\text { reduction, } \\
\text { molten salt } \\
\text { electrolysis }\end{array}$ & $\begin{array}{l}\text { High purity of RE chlorides } \\
(\sim 98 \%) \text {; applicable to } \\
\text { nonoxidized and oxidized alloys }\end{array}$ & $\begin{array}{l}\text { Require further processing to } \\
\text { obtain Nd alloy, consumption } \\
\text { of large amounts of chlorine } \\
\text { gas, Aluminum chloride is } \\
\text { very corrosive }\end{array}$ & {$[29,30,55,56]$} \\
\hline 2 & $\begin{array}{l}\text { Gas- } \\
\text { solid }\end{array}$ & $\mathrm{Nd}_{2} \mathrm{O}_{3}$ & $\begin{array}{l}\text { Molten salt } \\
\text { electrolysis } \\
\text { using Fe to } \\
\text { produce } \mathrm{Nd}- \\
\mathrm{Fe}\end{array}$ & $\begin{array}{l}\mathrm{FeCl} \text { recycled back using } \mathrm{HCl} \\
\text { formed in pyrohydrolysis; high } \\
\text { purity ( } \sim 99 \%) \text {; applicable to } \\
\text { nonoxidized and oxidized alloys }\end{array}$ & $\begin{array}{l}\text { Chlorination requires relatively } \\
\text { high temperatures and long } \\
\text { reaction times }\end{array}$ & {$[31,32]$} \\
\hline 3 & $\begin{array}{l}\text { Liquid- } \\
\text { solid }\end{array}$ & $\mathrm{NdCl}_{3}$ & $\begin{array}{l}\text { Metallothermic } \\
\text { reduction }\end{array}$ & $\begin{array}{l}\mathrm{MgCl} \text { can be recycled back as } \\
\text { extractant, more than } 80 \% \mathrm{RE} \\
\text { recovery }\end{array}$ & Long reaction time & {$[33]$} \\
\hline 4 & $\begin{array}{l}\text { Liquid- } \\
\text { solid }\end{array}$ & $\mathrm{NdCl}_{3}$ & $\begin{array}{l}\text { Metallothermic } \\
\text { reduction }\end{array}$ & Up to $90 \%$ RE recovery & $\begin{array}{l}\text { Require further processing to } \\
\text { obtain } \mathrm{Nd} \text { alloy }\end{array}$ & {$[34]$} \\
\hline 5 & $\begin{array}{l}\text { Solid- } \\
\text { liquid }\end{array}$ & $\begin{array}{l}\text { Nd metal, } \\
\mathrm{Nd}_{2} \mathrm{O}_{3}\end{array}$ & & $\begin{array}{l}\text { Simple process without flux } \\
\text { addition, }\end{array}$ & $\begin{array}{l}\text { High energy consumption for } \\
\text { oxidation }\end{array}$ & {$[10]$} \\
\hline 6 & $\begin{array}{l}\text { Gas- } \\
\text { solid }\end{array}$ & $\mathrm{NdFeB}$ alloy & & $\begin{array}{l}\text { Easy operation, master alloy can } \\
\text { be obtained }\end{array}$ & $\begin{array}{l}\mathrm{CO} / \mathrm{CO}_{2} \text { formation; carbon and } \\
\text { calcium impurities affect } \\
\text { magnetic properties }\end{array}$ & {$[9,35-37]$} \\
\hline 7 & $\begin{array}{l}\text { Liquid- } \\
\text { liquid }\end{array}$ & $\begin{array}{c}\mathrm{Nd}_{2} \mathrm{O}_{3}- \\
\mathrm{B}_{2} \mathrm{O}_{3}\end{array}$ & $\begin{array}{l}\text { Molten salt } \\
\text { electrolysis }\end{array}$ & $\begin{array}{l}\text { Good separation of RE and iron } \\
\text { (good RE recovery), } 99 \% \\
\text { extraction ratio and } 96 \% \text { purity }\end{array}$ & $\begin{array}{l}\text { Need further process to separate } \\
\text { Nd oxide from Boron oxide }\end{array}$ & {$[38]$} \\
\hline 8 & $\begin{array}{l}\text { Liquid- } \\
\text { liquid }\end{array}$ & NdFeB alloy & $\begin{array}{l}\text { Molten salt } \\
\text { electrolysis to } \\
\text { recover Nd }\end{array}$ & $\begin{array}{l}\text { Direct recycling of magnet alloy } \\
\text { by removing oxide } \\
\text { contaminants; low energy } \\
\text { consumption; no waste solution } \\
\text { generated }\end{array}$ & $\begin{array}{l}\text { Need further process to recover } \\
\text { loss Nd in alloy and recovery } \\
\text { of Nd from oxides }\end{array}$ & {$[28]$} \\
\hline 9 & $\begin{array}{l}\text { Gas- } \\
\text { solid }\end{array}$ & $\begin{array}{l}\text { Nd } \\
\text { compounds }\end{array}$ & $\begin{array}{l}\text { Molten salt } \\
\text { electrolysis }\end{array}$ & Good separation of RE from iron & $\begin{array}{l}\text { Require further processing to } \\
\text { obtain Nd alloy }\end{array}$ & [39] \\
\hline 10 & $\begin{array}{l}\text { Liquid- } \\
\text { solid }\end{array}$ & Nd metal & & $\begin{array}{l}\text { More than } 95 \% \text { RE recovery; } \\
\text { REEs in metallic state; } \\
\text { Mg rich Nd can be used as master } \\
\text { alloy for REPM; } \\
\text { Mg can be recycled }\end{array}$ & $\begin{array}{l}\text { Long reaction time; } \\
\text { Uneconomical if using fresh } \\
\mathrm{Mg} \text {; } \\
\text { Cannot be applied to oxidized } \\
\text { magnets }\end{array}$ & {$[40-43]$} \\
\hline 11 & $\begin{array}{l}\text { Liquid- } \\
\text { solid }\end{array}$ & $\mathrm{Nd}_{2} \mathrm{O}_{3}$ & $\begin{array}{l}\text { Molten salt } \\
\text { electrolysis }\end{array}$ & $\begin{array}{l}\text { More than } 90 \% \text { RE recovery; } \\
\text { Mg can be recycled }\end{array}$ & $\begin{array}{l}\text { Long reaction time; } \\
\text { Uneconomical if using fresh } \mathrm{Ag}\end{array}$ & {$[44]$} \\
\hline 12 & $\begin{array}{l}\text { Gas- } \\
\text { solid }\end{array}$ & $\begin{array}{l}\mathrm{NdFeB} \mathrm{HD} \\
\text { powder }\end{array}$ & & $\begin{array}{l}\text { Less energy input required } \\
\text { compared to other routes, no } \\
\text { waste generated, especially } \\
\text { suited for hard disk drives (little } \\
\text { compositional change over the } \\
\text { years) }\end{array}$ & $\begin{array}{l}\text { Not applicable to mixed scrap } \\
\text { feed, which contains magnets } \\
\text { with large compositional } \\
\text { variations; not applicable to } \\
\text { oxidized magnets; } \\
\text { Decreased magnetic power }\end{array}$ & {$[13,45-50]$} \\
\hline 13 & $\begin{array}{l}\text { Liquid- } \\
\text { solid }\end{array}$ & $\begin{array}{l}\text { NdFeB melt } \\
\text { spun } \\
\text { powder }\end{array}$ & & $\begin{array}{l}\text { Less energy input required than } \\
\text { other routes }\end{array}$ & $\begin{array}{l}\text { Only applicable to epoxy resin } \\
\text { bonded magnet }\end{array}$ & {$[51]$} \\
\hline 14 & $\begin{array}{l}\text { Liquid- } \\
\text { solid }\end{array}$ & $\mathrm{Nd}-\mathrm{Ni}$ alloy & & $\begin{array}{l}\text { Allows for the simultaneous } \\
\text { extraction and separation }\end{array}$ & $\begin{array}{l}\text { Not applicable to mixed scrap } \\
\text { feed, limited cell design }\end{array}$ & {$[54-56]$} \\
\hline
\end{tabular}

\section{Recycling or Recovery via Oxidation}

Nonmetallic elements such as carbon or oxygen are often considered as contaminants in REPM recycling and the formation of RE oxides or carbides can be detrimental in some pyrometallurgical recycling routes (e.g., in liquid metal extraction route and hydrogen decrepitation process). This is due to the formation of slag during heating/melting which results in a significant loss of REs due to the strong affinity of REs for oxygen. The physical separation of 
Fig. 5 Map of parameters (time and temperature) investigated. The points (filled circles) indicate the highest RE recovery (optimal temperature and time) of the process and the bars refer to the range of parameters (time and temperature) studied; $T_{\mathrm{m}}$ is the typical melting point of the magnet (Color figure online)

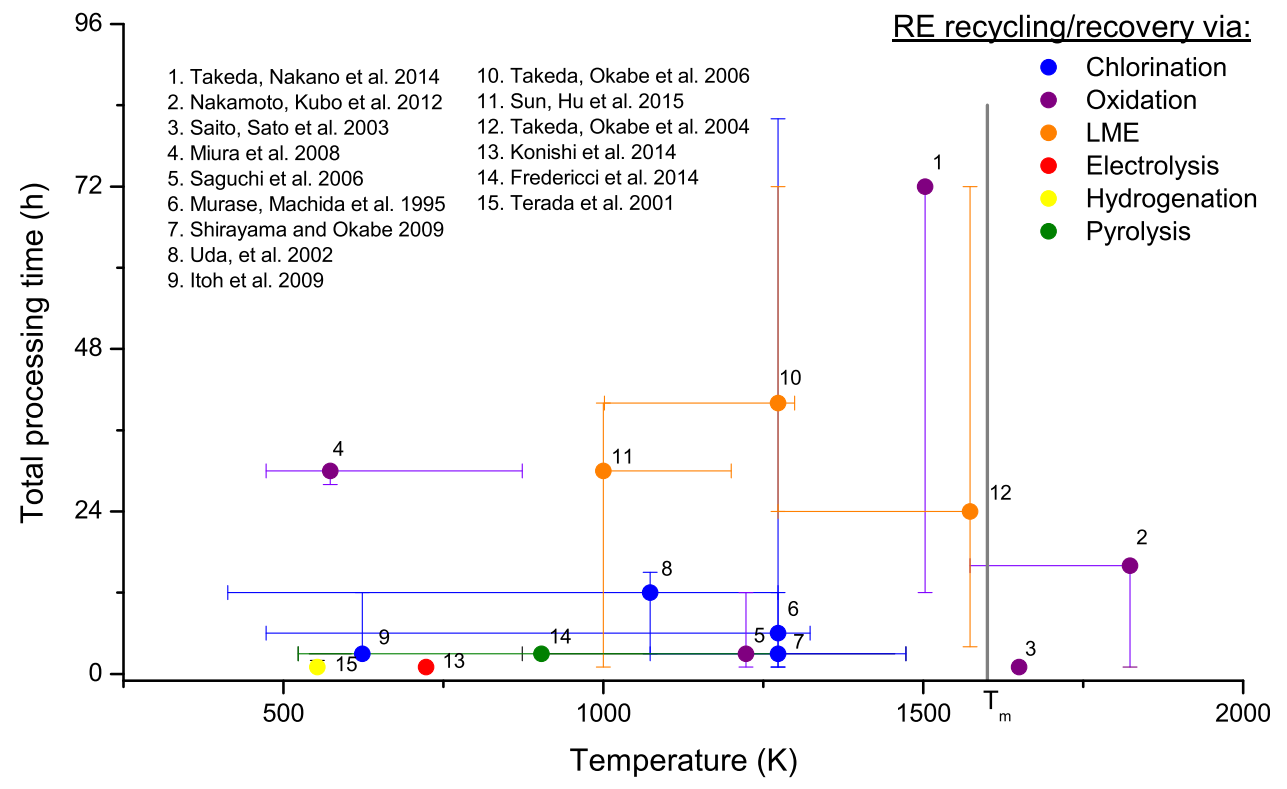

metal from slag is currently a serious technical challenge. These nonmetallic elements, if present in the materials manufactured from the recovered REs, may degrade magnetic properties. Oxides also present many technical problems on melting, partially because the melting temperature is very high (the melting temperatures of pure RE oxides $\mathrm{Dy}_{2} \mathrm{O}_{3}$ and $\mathrm{Pr}_{2} \mathrm{O}_{3}$ are higher than $2273 \mathrm{~K}$, and $\mathrm{Nd}_{2} \mathrm{O}_{3}$ is $\sim 2593 \mathrm{~K}$ ). The RE oxide (REO) flux prevents sound casting due to its high viscosity and reactivity with other oxides such as alumina. However, due to the stability of REOs and their high occurrence in REPM swarf, the control of oxides is important in the recycling process.

The method of using the difference in oxygen affinities between REEs and Fe is potentially more environmentally friendly than other methods because it avoids the use of acids and halides. REPM recycling via oxides can in general be categorized into (1) processes in which the magnet is oxidized or melted, and the oxygen is then removed by reduction or substitution; and (2) processes which extract REs as oxides form from magnet scrap that usually involves remelting the waste (Fig. 6). Of the first recycling routes (refining type) in Fig. 4, the two widely known oxidation routes are Nos. 6 and 8, developed, respectively, by Saguchi et al. [37] and by Takeda et al. [28]. As summarized in Tables 1 and 2, the former removes oxygen using calciothermic reduction to reduce REOs without melting the magnet, while the latter uses flux to extract REOs from the waste to recover $\mathrm{Nd}-\mathrm{Fe}-\mathrm{B}$ alloy. The second group includes processes by Saito et al. [38], who developed the RE recovery process using glass slag whereby RE contained in REPM waste are oxidized and extracted into $\mathrm{B}_{2} \mathrm{O}_{3}$ flux (Route No. 7 in Tables 2 and 3 ) and the method developed by Nakamoto et al. [10] to separate REO from Fe-B using carbon as contact material (Route No. 9 in Tables 2 and 3).

\section{NdFeB's Oxidation Thermodynamics, Kinetics, and Mechanism}

Since the 1980s when NdFeB magnets were commercialized, the corrosion and oxidation behaviors of $\mathrm{NdFeB}$ magnets have been extensively studied particularly the degradation of magnetic properties at temperatures up to $873 \mathrm{~K}$. Figure 7 shows the standard Gibbs energy of typical oxides that can form during the heat treatment of $\mathrm{Nd}$-based magnets. The typical REOs are $\mathrm{Nd}_{2} \mathrm{O}_{3}, \mathrm{Dy}_{2} \mathrm{O}_{3}$, $\mathrm{Pr}_{2} \mathrm{O}_{3}$. Oxides from alloying elements may also form, such as $\mathrm{B}_{2} \mathrm{O}_{3}, \mathrm{Fe}_{2} \mathrm{O}_{3}$, and $\mathrm{Fe}_{3} \mathrm{O}_{4}$. It has been widely reported that the $\mathrm{Nd}_{2} \mathrm{Fe}_{14} \mathrm{~B}$ phase decomposes to $\alpha-\mathrm{Fe}, \mathrm{Fe}_{2} \mathrm{~B}$, and $\mathrm{Nd}_{2} \mathrm{O}_{3}$ in oxygen as a follows [10, 38, 39, 57]:

$$
\begin{aligned}
& \mathrm{Nd}_{2} \mathrm{Fe}_{14} \mathrm{~B}(\mathrm{~s})+3 / 2 \mathrm{O}_{2}(\mathrm{~g}) \rightarrow 12 \mathrm{Fe}(\mathrm{s})+\mathrm{Fe}_{2} \mathrm{~B}(\mathrm{~s}) \\
& \quad+\mathrm{Nd}_{2} \mathrm{O}_{3}(\mathrm{~s}) \quad<500 \mathrm{~K} \\
& 2 \mathrm{Fe}(\mathrm{s})+3 / 2 \mathrm{O}_{2}(\mathrm{~g}) \rightarrow \mathrm{Fe}_{2} \mathrm{O}_{3}(\mathrm{~s})<750 \mathrm{~K} \\
& \mathrm{Fe}_{2} \mathrm{O}_{3}(\mathrm{~s})+\mathrm{Nd}_{2} \mathrm{O}_{3}(\mathrm{~s}) \rightarrow 2 \mathrm{FeNdO}_{3}(\mathrm{~s})>750 \mathrm{~K}
\end{aligned}
$$

Thermogravimetric analysis (TGA) from early studies at around $573 \mathrm{~K}$ showed that rapid surface oxidation with formation of a thin powdered layer on uncoated REPM takes place within the first minute, and this can be substantial as the average particle size decreases [58-60]. It was suggested that this surface oxide layer does not effectively inhibit further diffusion of oxygen. Energy dispersive X-ray (EDS) analysis showed that iron oxide formed at room temperature in humid air, with a small 
Fig. 6 Recovery process of RE from REPM scrap by remelting with flux

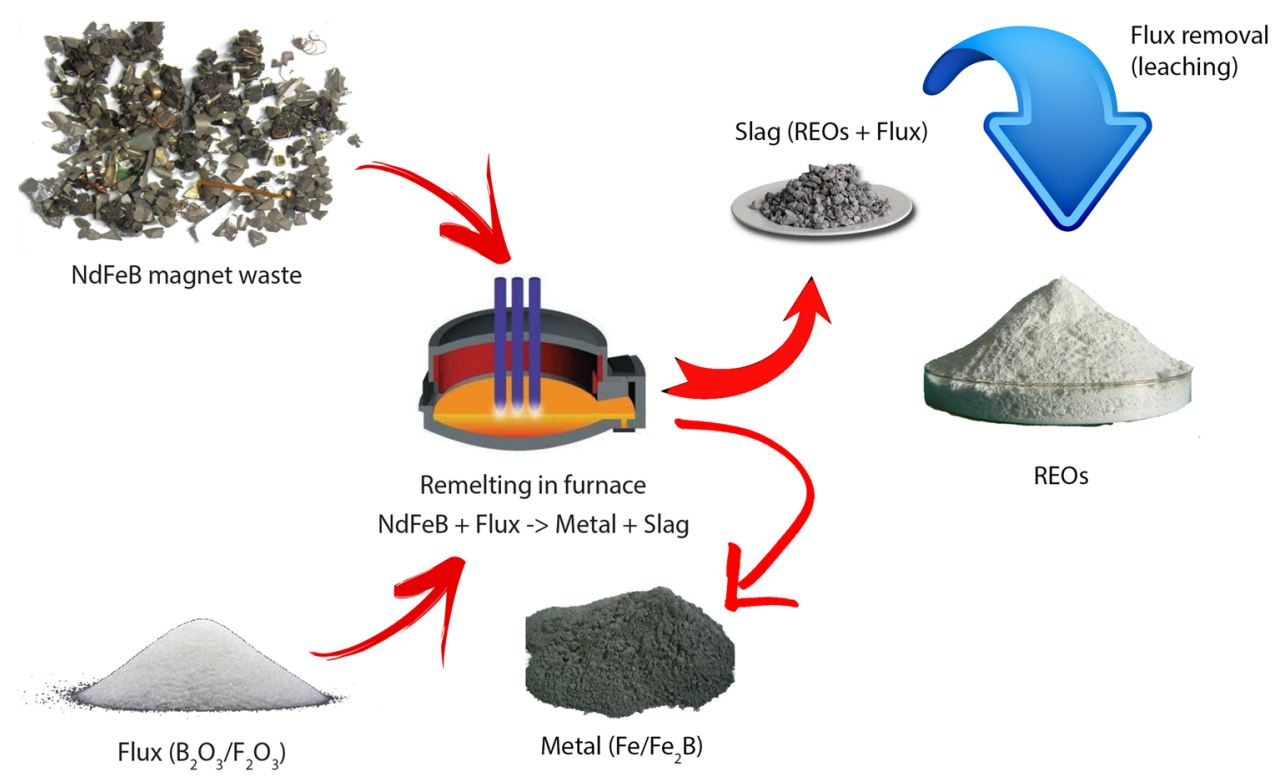

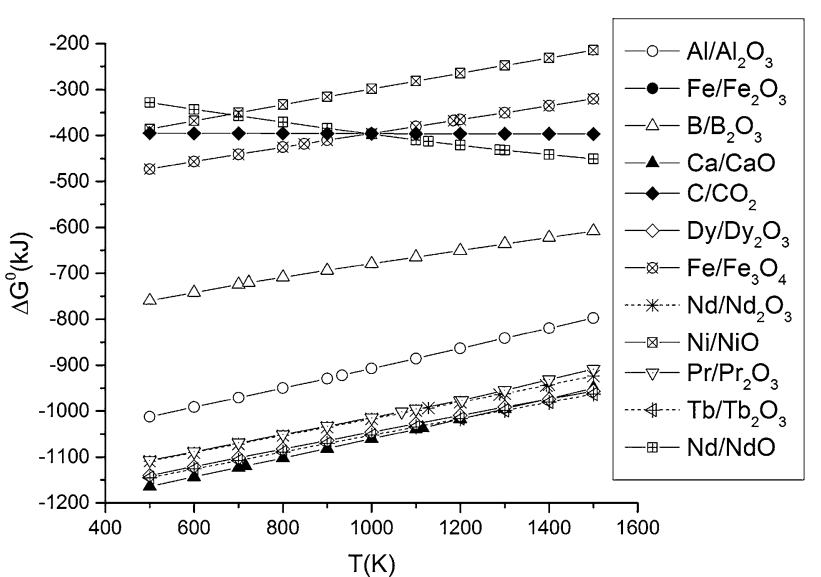

Fig. 7 Ellingham diagrams of oxides for base alloy elements and typical coating elements in REPM

amount of $\mathrm{Nd}_{2} \mathrm{O}_{3}$ also formed but at $423 \mathrm{~K}$ the oxidation product became mostly $\mathrm{Nd}_{2} \mathrm{O}_{3}$ [58].

Microstructures of the material have been studied to help understand the mechanism of oxidation [18, 61-64]. Outer scales or external oxidation zone (EOZ), identified as $\mathrm{Fe}_{2} \mathrm{O}_{3}$ and $\mathrm{Fe}_{3} \mathrm{O}_{4}$ by scanning electron microscopy (SEM), were found to form at $573-873 \mathrm{~K}$ and zones of internal oxidation were also observed, confirming that the principal degradation process is by inward diffusion of oxygen. The depth of the internal oxidation zone (IOZ) increased parabolically with time, consistent with parabolic oxidation behavior observed from TGA studies [57, 58, 64]. The IOZ was reported to consist of an $\alpha$-Fe matrix containing a dispersion of small (2-nm diameter) particles of $\mathrm{NdO}$ with amorphous structure. No degradation of the $\mathrm{Nd}_{2} \mathrm{Fe}_{14} \mathrm{~B}$ phase in the grains was found using conversion electron Mössbauer spectroscopy (CEMS), and analysis by transmission spectroscopy (TMS) confirmed that dissociation of the grain is unlikely and happens only when it reacts with oxygen [59]. As such, there is no diffusion of $\mathrm{Nd}$ into the IOZ. It is believed that the oxygen transport occurs by short-circuit diffusion, and the most likely diffusion paths are the $\alpha$-Fe grain boundaries which are shown to be highangle grain boundaries. A schematic diagram of IOZ formation in REPM oxidation is shown in Fig. 8. The internal-oxidation kinetics have been described in terms of Wagner's model as modified by Maak to account for the presence of an external oxide layer [57]. Over the temperature range $423-873 \mathrm{~K}$, the IOZ thickness $\chi$ can be calculated using Eq. 4,

$\chi=(k(T) t)^{1 / 2}$

where $t$ is the reaction time, and $k(T)$ is the parabolic rate constant, which is a function of temperature. The value of $k(T)$ also depends on microstructural features. Changes to the basic $\mathrm{Nd}_{16} \mathrm{Fe}_{76} \mathrm{~B}_{8}$ composition might also change the microstructure of the IOZ and have a corresponding effect on the oxidation kinetics. Steyaert et al. [66] concluded that, based on their microstructural study, both particle size and temperature range play important parts in the determination of the kinetic parameters of $\mathrm{Nd}-\mathrm{Fe}-\mathrm{B}$ powder's oxidation. Parida et al. [67] studied the oxygen potential diagram for the system $\mathrm{Nd}-\mathrm{Fe}-\mathrm{O}$ at $1350 \mathrm{~K}$, and the oxygen potentials corresponding to the equilibria between alloys/intermetallics and $\mathrm{Nd}_{2} \mathrm{O}_{3}$ (s) are shown in Fig. 9. On reducing the oxygen partial pressure at $1350 \mathrm{~K}$, $\mathrm{NdFeO}$ (s) dissociates to $\mathrm{Fe}(\mathrm{s})$ and $\mathrm{Nd}_{2} \mathrm{O}_{3}(\mathrm{~s})$. 
Fig. 8 Schematic diagram showing the process of grain coarsening as the IOZ thickens with time by inward oxygen diffusion along $\alpha$-Fe high-angle grain boundaries [65]
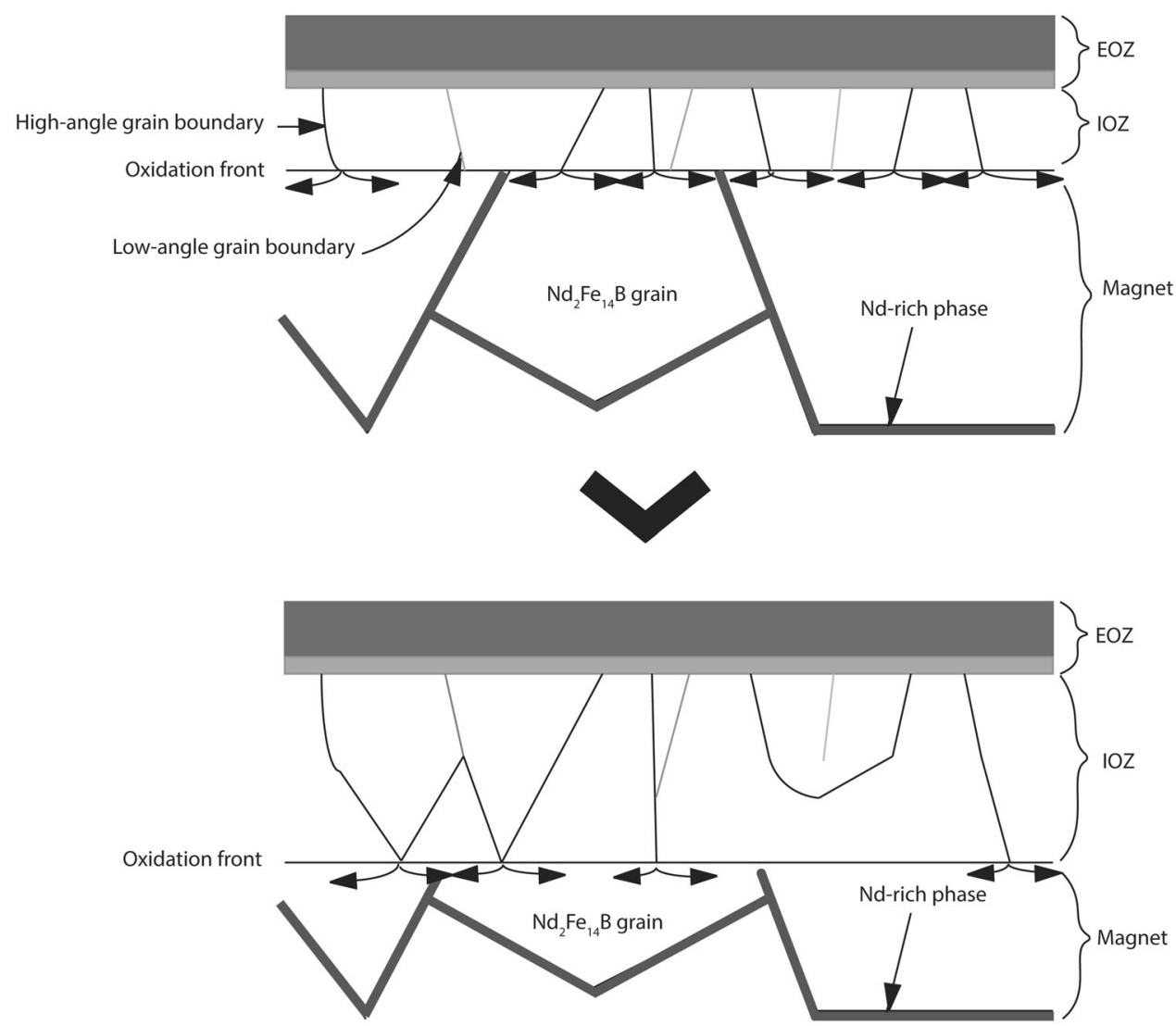

\section{Removal of Oxygen from Oxidized Magnet (Refining Method)}

Suzuki et al. and Saguchi et al. [9, 35, 37] studied the removal of carbon and oxygen from magnet scrap. In principle, the technique was based on the calcium halide flux deoxidation technique for RE metals. The scrap was first decarburized by oxidation at $1073 \mathrm{~K}$ to convert the carbon to carbon dioxide, and then oxygen was removed in a two stage reduction. First, $\mathrm{Fe}_{2} \mathrm{O}_{3}$ was reduced by hydrogen gas at $1253 \mathrm{~K}$ then the REOs were reduced metallothermically with calcium at $1223 \mathrm{~K}$. Residual $\mathrm{Ca}$, by-product $\mathrm{CaO}$, and $\mathrm{CaCl}_{2}$ were leached with water and removed. The carbon, calcium, and oxygen contents of the reduced metal were less than $0.001,0.7$ and $0.1 \mathrm{wt} \%$, respectively.

The recycling process, although involving several steps, can be considered as a simple process utilizing basic reduction methods and is easy to operate. The decarburization of the sludge has also been found to be possible under vacuum, with most of the oxygen source coming from the sludge itself [35]. Hydrogenation of the decarburized scraps is done to reduce the $\mathrm{Ca}$ consumption in the second stage reduction because iron oxide hinders the subsequently $\mathrm{Ca}$ reduction-more $\mathrm{Ca}$ is required for reduction of $\mathrm{Fe}_{2} \mathrm{O}_{3}$, increasing the recycling cost, and the
Fig. 9 Oxygen potential diagram for the system $\mathrm{Nd}-\mathrm{Fe}-\mathrm{O}$ at $1350 \mathrm{~K}$ [67] 
reduction of $\mathrm{Fe}_{2} \mathrm{O}_{3}$ by $\mathrm{Ca}$ is exothermic [9]. Although the mechanism of hydrogenation was not clearly described, it is known that the $\mathrm{Nd}-\mathrm{Fe}-\mathrm{B}$ phase decomposes into a mixture of $\mathrm{Nd}$ hydrides, $\alpha-\mathrm{Fe}$, and $\mathrm{Fe}-\mathrm{B}$ phases by hydrogenation as described in Eq. 10 [39, 45-47]. The hydrogen-reduced scrap consisted mainly of $\mathrm{NdFeO}_{3}$ in the interior, $\alpha-\mathrm{Fe}$ at the exterior of the granule and $\mathrm{NdBO}_{3}$ as minor product, with oxygen concentration being around 7-8 mass $\%$.

The second stage reduction process was controlled by the addition of $\mathrm{CaCl}_{2}$. The mechanism of the calcium reduction was explained as follows. $\mathrm{Ca}$ attaches to the sample surface, and the layer of $\mathrm{CaO}$ by-product surrounds the sample during reduction or deoxidation. This $\mathrm{CaO}$ layer is removed by dissolution in $\mathrm{CaCl}_{2}$ in order to enhance the subsequent deoxidation by $\mathrm{Ca}$ [36]. Removing residual $\mathrm{Ca}$ is important due to its significant effect on the magnetic properties of the recycled product. The addition of $\mathrm{CaCl}_{2}$ enhanced the dissolution of the by-product $\mathrm{CaO}$ into the aqueous solution during leaching, but too much addition reduced the concentration of RE elements in the sample. Leaching using distilled water at $\mathrm{pH}$ higher than 8 is preferred due to the fact that acid can remove some of the RE as well.

Takeda et al. [28] investigated a process to refine waste magnets using mixed salt fluoride flux which exploited the high solubility of REOs in molten fluoride to separate the REOs from the magnet alloy. The RE in the mixed salt flux substituted the lost RE from REOs removal. The refined alloys can then be used as master alloys for magnets, and the REOs are regenerated as RE metals using molten salt electrolysis. The oxygen concentration in the magnet alloy waste was reduced from $5000 \mathrm{ppm}$ to less than $200 \mathrm{ppm}$ (exceeding $90 \%$ extraction ratio). Importantly, less energy was consumed by regenerating the magnet alloys without oxidation, and there was much less waste generated.

The process is relatively simple. The flux consisting of LiF-50 mol\% $\quad \mathrm{NdF}_{3}$ and LiF-25 mol\% $\mathrm{NdF}_{3}-25 \mathrm{~mol} \%$ $\mathrm{DyF}_{3}$ is used, and the remelting temperature is about $1503 \mathrm{~K}$, just above the peritectic point of $1454 \mathrm{~K}$. The matrix of the magnet alloy decomposes into $\gamma$-Fe and liquid $\mathrm{Nd}-\mathrm{Fe}-\mathrm{B}$ phases due to the peritectic reaction during solidification (Fig. 2). Above the peritectic point, the REOs in the alloy are liberated. The solubility of REOs in the fluoride flux at this temperature was estimated to be around $7.4 \mathrm{wt} \%$. REOs (mainly $\mathrm{Nd}_{2} \mathrm{O}_{3}$ ) were extracted in the form of the oxyfluoride $\mathrm{Nd}_{4} \mathrm{O}_{3} \mathrm{~F}_{6}$ from the reaction with $\mathrm{NdF}_{3}$ in the flux. This approach can be considered highly practical for industrial use. It is likely to develop as a favored recycling process with the advantage of having a short recycling path that does not require wastes to be fed back into the smelting process. The dissolution rates and behaviors of elements in the melts under such condition are key aspects that might be considered in further studies of this process. The dissolution rate can be increased for practical application by employing a device to give strong agitation of the melts.

\section{Separation of RE as REOs from Oxidized Magnet Waste}

Nakamoto et al. [10] efficiently removed iron from highly oxidized magnet alloy sludge as a molten $\mathrm{Fe}-\mathrm{C}$ alloy by adding carbon to decrease the melting temperature of the iron alloy. The separation of RE elements (Nd, Dy, and Pr) and $\mathrm{Fe}$ is based on the difference in the nature of oxidation between the REEs and $\mathrm{Fe}$. The region of coexistence of $\mathrm{Fe}$ and REO $\left(\mathrm{Nd}_{2} \mathrm{O}_{3}\right)$ extends over a wide range of oxygen partial pressures as depicted in Fig. 9. To create this oxygen partial pressure, carbon was selected as a contact material. The oxygen partial pressures are approximately $10^{-17}$ atm under the experimental conditions and were within the coexistence zone between the REOs and metallic Fe (Fig. 9). From Fig. 7, it is evident that carbon can readily reduce iron oxide at $1273 \mathrm{~K}$ and higher. The separation temperature of $1823 \mathrm{~K}$ was selected because one phase must be liquid for separation. The melting temperature of the iron was chosen as it is lower. The molten magnet alloy separated into liquid metal and oxide phases at this temperature. The liquid metal phase is then separated by magnetic separation. By this route, the concentration of REs (neodymium, dysprosium, and praseodymium) in the metallic phase was able to be reduced to less than $0.01 \mathrm{wt} \%$. The fluidity of the melts is important for effective separation. The temperature and holding time need to be controlled to reduce $\mathrm{B}$ concentration in the oxide phase. Increasing the holding time reduces B concentration in the oxide phase but results in the reduction in $\mathrm{RE}$ recovery from the metal phase. Changing temperature affects viscosity and fluidity of the melts which may result in reduced separation efficiency. Nakamoto et al. [10] also found that $\mathrm{B}_{2} \mathrm{O}_{3}$ addition contributes to an efficient separation at reduced temperature of $1623 \mathrm{~K}$ by reducing the melting temperature of the oxide phase and increasing the viscosity.

Saito et al. [38] developed a method using a glass slag whereby magnet scrap is melted and brought into contact with a molten flux exploiting the strong affinity of REs with the slag. During undercooling, a reaction between molten alloy and flux takes place to selectively dissolve the REs from the alloys and supercool to a glass. In this method, RE contained in magnet alloys were first oxidized and extracted into $\mathrm{B}_{2} \mathrm{O}_{3}$ flux leaving behind $\alpha-\mathrm{Fe}$ and $\mathrm{Fe}_{2} \mathrm{~B}$ phases. The alloy was oxidized through slow heating and melting, up to superheated temperature of $1650 \mathrm{~K}$, then cooled to room temperature in an argon atmosphere. 
During undercooling, the $\mathrm{Nd}_{2} \mathrm{Fe}_{14} \mathrm{~B}$ phase reacts with $\mathrm{B}_{2} \mathrm{O}_{3}$ to form $\alpha-\mathrm{Fe}$ and $\mathrm{Fe}_{2} \mathrm{~B}$ phases together with $\mathrm{Nd}$ oxide. The REs are separated and concentrated through the formation of $\mathrm{RE}_{\mathrm{x}} \mathrm{O}_{\mathrm{y}}-\mathrm{B}_{2} \mathrm{O}_{3}$ melt, which contains $50 \mathrm{wt} \% \mathrm{RE}_{\mathrm{x}} \mathrm{O}_{\mathrm{y}}$ and $\mathrm{B}_{2} \mathrm{O}_{3}$ melt (immiscibility gap). The concentrations of REs (neodymium, dysprosium, and praseodymium) in the iron alloy were lowered to less than 0.01 mass $\%$, and almost all REs were extracted into the slag phase. The REs could be recovered from the slag by dissolving the slag in sulfuric acid followed by selective precipitation of the REs as a sulfate double salt or hydroxide [68]. The oxides could also be leached with hydrochloric acid and precipitated as an oxalate. Although this method is suitable for the large-scale treatment of magnet wastes containing iron, it generates a lot of inorganic waste. Bian et al. [14] improved this method by using $\mathrm{FeO}-\mathrm{B}_{2} \mathrm{O}_{3}$ fluxes to increase the selectivity of neodymium oxidation and separation of RE with $\mathrm{Fe}$. The $\mathrm{FeO}$ selectively reacts with neodymium and will be reduced in molten flux due to its larger chemical potential compared to $\mathrm{B}_{2} \mathrm{O}_{3}$. At $1673-1823 \mathrm{~K}$, almost all REEs in the magnet scraps were extracted to the oxide phase, and the $\mathrm{FeO}$ in the flux was reduced entirely to metal. Only boron was distributed in both oxide and metal phases. However, the purity of the RE oxides extracted fluctuated and was rather low. The main concern was the formation of $\mathrm{REBO}_{3}$ in the oxide phase (and the potential loss of REs) which reduces the purity of the REOs. The extraction ratios of all REEs were more than 99.5 mass \%, and the purity of the REOs was greater than 96 mass $\%$ when using $2 \mathrm{FeO} \cdot \mathrm{B}_{2} \mathrm{O}_{3}$ flux. The purity of the RE improved apparently with the increase of reaction time.

Miura et al. [39] effectively recovered $\mathrm{Fe}$ from $\mathrm{Nd}-\mathrm{Fe}-\mathrm{B}$ sintered magnet powder scrap as $\mathrm{Fe}(\mathrm{CO})_{5}$ via the carbonylation reaction using chalcogen catalysts and leaving compounds containing $\mathrm{RE}$ as REOs and/or $\mathrm{REH}_{2}$. The carbonylation reaction has previously been applied to extract or purify transition metals. The process is similar to the production of highly pure nickel from the crude nickel by the Mond process. Iron reacts directly with carbon monoxide gas under high-pressure and temperature conditions to form $\mathrm{Fe}(\mathrm{CO})_{5}$. The reaction conditions were $573 \mathrm{~K}$ under $30 \mathrm{MPa}$ for $24 \mathrm{~h}$. The rate of carbonylation is considerably controlled by the presence of $\mathrm{S}$. Fe needs to be disassociated from the $\mathrm{Nd}_{2} \mathrm{Fe}_{14} \mathrm{~B}$ phase for the reaction to proceed because the carbonylation reaction proceeds via a $\mathrm{FeS}-\mathrm{CO}$ intermediate complex and the $\mathrm{S}$ have low reactivity with $\mathrm{Fe}$ in the $\mathrm{Nd}-\mathrm{Fe}-$ $\mathrm{B}$ lattice. Oxidation and/or hydrogenation is performed before carbonylation to precipitate $\alpha$-Fe because $\mathrm{Nd}_{2} \mathrm{Fe}_{14} \mathrm{~B}$ is stable at the reaction temperature. Miura et al. [39] found that the oxidized powder gave low iron conversion of $58 \%$ compared to $90 \%$ using hydrogenation. This was due to the fact that $\mathrm{FeO}$ and $\mathrm{Fe}_{2} \mathrm{O}_{3}$ were formed during oxidation and are much more stable than FeS; thus, the FeS-CO intermediate is difficult to form on $\mathrm{FeO}$ or $\mathrm{Fe}_{2} \mathrm{O}_{3}$ through the carbonylation reaction. Furthermore, the RE products require further processing to remove unwanted impurities such as $\mathrm{Fe}_{2} \mathrm{~B}$.

\section{Recycling or Recovery via Chlorination}

Recovery of RE from REPM by the formation of RE chlorides has been developed to overcome the difficulties of dealing with oxides due to their high melting point and difficulty to separate. Chlorination is a relatively low cost simpler process which produces less effluent requiring treatment. However, its disadvantage is that the RE elements are recovered as chlorides, and these chlorides have limited application after recovery $[55,56]$. Both molten salt extraction and gas phase reactions can be used. Figure 12 shows the various chlorination routes. These are based on the selective reactions between REEs and extractants such as molten $\mathrm{FeCl}_{2}, \mathrm{NH}_{4} \mathrm{Cl}, \mathrm{Cl}_{2}$, and $\mathrm{AlCl}_{3}$. Gas phase chlorination and/or carbochlorination have mostly been used to recover metals such as vanadium, tantalum, niobium, molybdenum, nickel, and cobalt from scrap. Extraction of REs as chlorides in the gas phase was first applied to REPM by Murase et al. [29, 30] based on Adachi et al. [69] findings. The process was modified by Uda et al. [31, 32] (Route Nos. 1 and 2 in Tables 2 and 3), Mochizuki et al. $[55,56]$, and several others to increase the separation efficiency. The extraction of RE using molten salt (Route Nos. 2, 3, and 4 in Tables 2 and 3) was first introduced by Uda et al. [31, 32], in combination with distillation, and then by Okabe et al. [33] following their results in recycling using pure magnesium [42]. Itoh et al. [34] used the same method but using a different salt. Hua et al. [70] adapted the process by combining several salts to increase selectivity.

\section{NdFeB Chlorination's Thermodynamics, Kinetics, and Mechanism}

The Gibbs energy diagram for formation of chlorides from alloying elements is shown in Fig. 10 based on calculations using FactSage and data from Uda et al. [32]. The chemical potentials of chlorine at equilibrium between the RE metals and corresponding dichlorides are considerably lower than those at the equilibrium between the iron group metals and corresponding dichlorides. Thus, when RE metals coexist with the iron group metals in a metal mixture, RE metals can be selectively chlorinated. It is also be seen that the line for neodymium dichloride is considerably below that of neodymium trichloride which suggests that the concentration of divalent neodymium in the $\mathrm{FeCl}_{2}-\mathrm{NdCl}_{3}$ molten salt will be small.

There is little information on the kinetics of $\mathrm{NdFeB}$ chlorination by gaseous chlorine, but there are studies on 


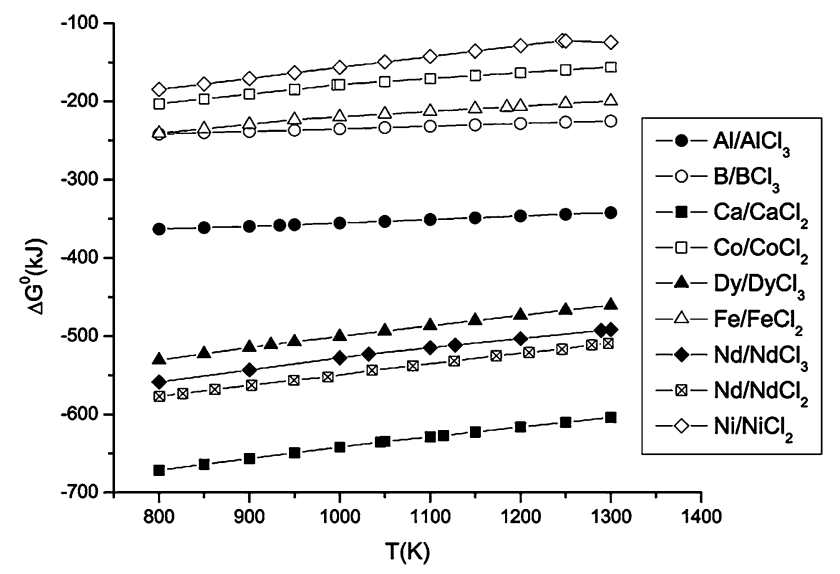

Fig. 10 Chemical potential of chlorine at each equilibrium [32]

$\mathrm{Nd}$ chlorination [71] and $\mathrm{Nd}_{2} \mathrm{O}_{3}$ [72, 73]. Bosco et al. [72] studied the thermodynamics and kinetics of neodymium oxide chlorination by gaseous chlorine. TGA measurement showed that reaction started at around $523 \mathrm{~K}$ at which $\mathrm{NdOCl}$ was formed by Eq. 5. No significant mass changes were observed between 683 and $1133 \mathrm{~K}$ signifying that at this temperature range the rate is controlled by diffusion. A mass decrease above $1133 \mathrm{~K}$ was explained by evaporation of $\mathrm{NdCl}_{3}(\mathrm{~s}, 1)$ produced by chlorination of $\mathrm{NdOCl}(\mathrm{s})$ through Eq. 6.

$$
\begin{aligned}
& \mathrm{Nd}_{2} \mathrm{O}_{3}(\mathrm{~s})+\mathrm{Cl}_{2}(\mathrm{~g}) \leftrightarrow 2 \mathrm{NdOCl}(\mathrm{s})+\frac{1}{2} \mathrm{O}_{2}(\mathrm{~g}) \\
& \mathrm{NdOCl}(\mathrm{s})+\mathrm{Cl}_{2}(\mathrm{~g}) \leftrightarrow \mathrm{NdCl}_{3}(\mathrm{~s}, \mathrm{l})+\frac{1}{2} \mathrm{O}_{2}(\mathrm{~g})
\end{aligned}
$$

It was concluded from a kinetic analysis that the reaction rate is not affected by mass transfer in the gas phase or through the sample pores but is under chemical control at temperatures below $700 \mathrm{~K}$. The Johnson-Mehl-Avrami equation for nucleation and growth reaction mechanism, with $n \approx 1.65$ (Eqs. 7 and 8), fits the results well. The activation energy was estimated to be $169 \pm 5 \mathrm{~kJ} / \mathrm{mol}$ and the reaction rate described as

$$
\begin{aligned}
\text { Rate }= & \frac{\mathrm{d} \alpha}{\mathrm{d} x} \\
= & 1.04 \times 10^{5}\left(\mathrm{~s} \mathrm{kPa}^{0.4}\right)^{-1} \times e^{-\left(\left(161 \mathrm{~kJ} \mathrm{~mol}^{-1}\right) / \mathrm{RT}\right)} \\
& \times \mathrm{pCl}_{2}^{0.39} \\
& \times\{1.65 \times(1-\alpha) \times[-\ln (1-\alpha)]\}^{0.39}
\end{aligned}
$$

and,

$\alpha=\frac{m_{\mathrm{t}}-m_{\mathrm{i}}}{m_{\mathrm{i}}} \times f$

where $m_{\mathrm{t}}$ and $m_{\mathrm{i}}$ are the sample masses at a given time and at the initial time, respectively; and $f$ is the stoichiometric factor for the formation of $\mathrm{NdOCl}(\mathrm{s})$ and is equal to 6.128 .
Hua et al. [70] investigated the kinetics and mechanism of REEs extraction using molten salt. The mechanism of extraction suggested from their study is depicted in Fig. 11 and can be described by the following steps: (1) transport of $\mathrm{MgCl}_{2}$ from bulk melt to the exterior surface of the ash layer through a melt boundary layer, (2) diffusion of molten reactant $\left(\mathrm{MgCl}_{2}\right)$ through the ash layer to the reaction surface, (3) chemical reaction of REEs with $\mathrm{MgCl}_{2}$, (4) diffusion of molten product $\left(\mathrm{RECl}_{3}\right)$ outward through the ash layer, and (5) transport of the molten product. Assuming that the extraction process follows the unreacted shrinking core model, different mechanisms (chemical reaction-controlled, diffusion-controlled, and the mixed-controlled) were evaluated. Hua et al. found that the kinetic plots for diffusion control gave a better linear relationship compared to the others, and they concluded that the rate-controlling step was diffusion. However, the rate equation was not established, and microstructural changes were not clearly investigated.

\section{Separation of RE from NdFeB by Solid-Gas Chlorination}

The fundamental idea of RE recovery by gas phase extraction process is based on chemical vapor transport (CVT) reactions investigated principally in the fields of preparation chemistry and separation chemistry. The main reasons that gas phase extraction of RE metals is difficult to apply are: firstly, $\mathrm{RE}$ chlorides (RECl) are less volatile and,

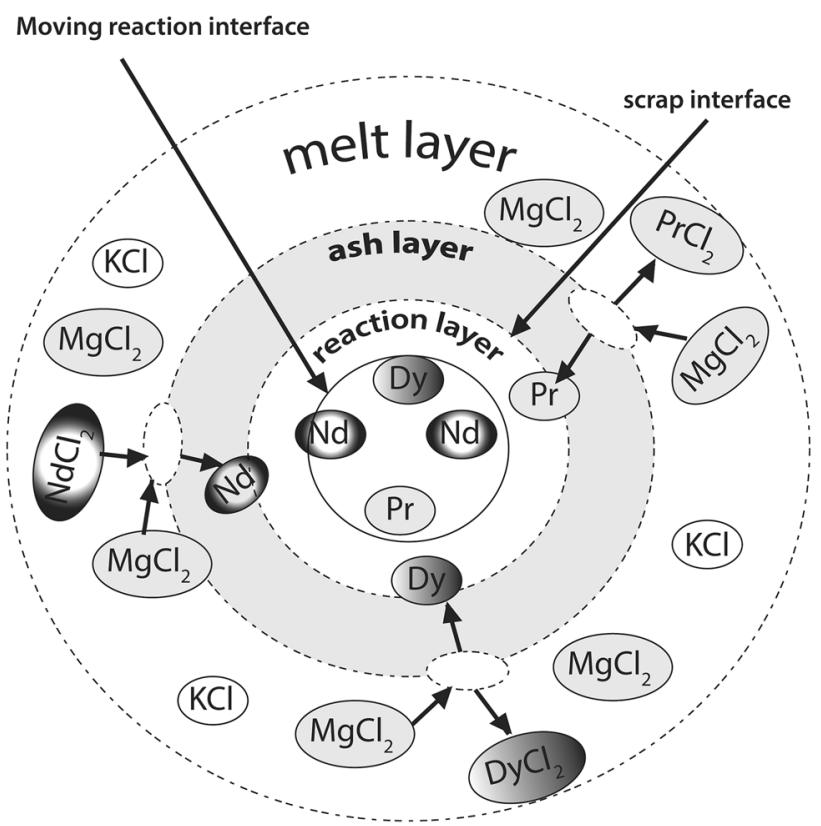

Fig. 11 Schematic diagram of the unreacted shrinking core model for the extraction of REs from $\mathrm{NdFeB}$ scrap, reprinted with permission from Hua et al. [70] 
therefore, difficult to separate from other less volatile metal chlorides, especially from alkaline-earth chlorides; secondly, extraction of the REs by gas phase chlorination requires relatively high temperatures and long reaction times; thirdly, RE chlorides have a very similar volatilities, so that mutual separation is not expected in the sublimation processes. In Murase et al. [29, 30] approach (Route No. 1 in Tables 2 and 3), the RE chlorides form halogen-bridged complex formers with alkali metal chlorides which leads to vast increase in vapor pressure and transport of the lessvolatile $\mathrm{RECl}$ through the reactor, which has a temperature gradient (sublimation chamber). $\mathrm{AlCl}_{3}(\mathrm{~g})$ is used as the complex former to enhance the volatility of $\mathrm{NdCl}_{3}$ by a factor of $10^{13}$. The purity of the $\mathrm{RECl}$ in the chloride mixture collected from the higher temperature section of the sublimation chamber $(1000-1300 \mathrm{~K})$ reached up to $98.4 \mathrm{~mol} \%$. The chlorides from the coating and additive elements, such as cobalt and nickel chlorides, were collected in the lower section (750-1000 K). The chlorides of other metals, such as iron, copper, zirconium, and aluminum, condensed at the outlet of the reactor $(<600 \mathrm{~K})$. The inherent disadvantage of this process is the nonselective nature of the chlorination and the high corrosiveness of aluminum chloride, which hydrolyzed with formation of hydrogen chloride gas, even when the slightest amount of water is present (Fig. 12).

Mochizuki et al. [55, 56] investigated the separation Pr/Dy in REPM and the effect of oxidation on gas phase chlorination and carbochlorination. Instead of a CVT reaction, they used distillation which utilizes the disparities in vapor pressure (Fig. 13) caused by differences in the oxidation state of the chlorides, similar to the approach of Uda et al. [31, 32]. As

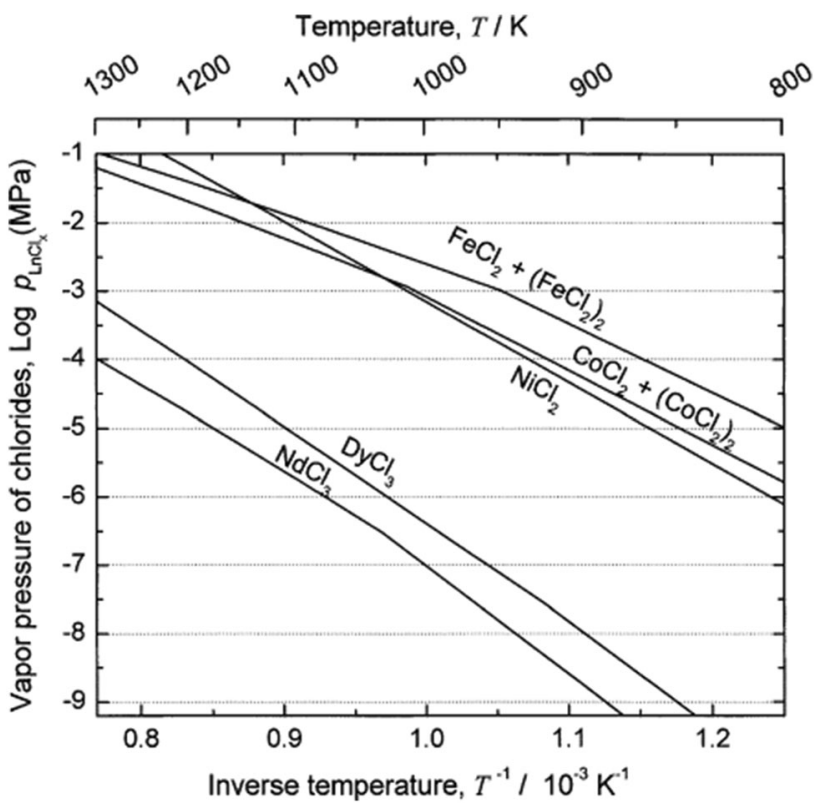

Fig. 13 Vapor pressures of metal chlorides as a function of temperature [32]

seen from Fig. 13, the vapor pressures of dichloride of the iron group elements are three orders of magnitude larger than those of RE trichlorides. Mochizuki et al. [55, 56] found that oxidation had significant impacts on B and Fe volatilization and reduced the separation efficiency. A higher chlorine rate was required to fully chlorinate the oxidized samples compared to the unoxidized sample (Table 4). Oxidized RE magnets were crushed to less than $74 \mu \mathrm{m}$ and heated with chlorine. The volatilization of the elements from oxidized samples during chlorination increased in the order
Fig. 12 Schematic diagrams of RE recovery using chlorination: [a] Murase et al. [29, 30],

[b] Mochizuki et al. [55, 56],

[c] Uda et al. [31, 32],

[d] Shirayama et al. [33],

[e] Hua et al. [70], [f] Itoh et al. [34]
Molten Salt Extraction

Gas Phase Extraction

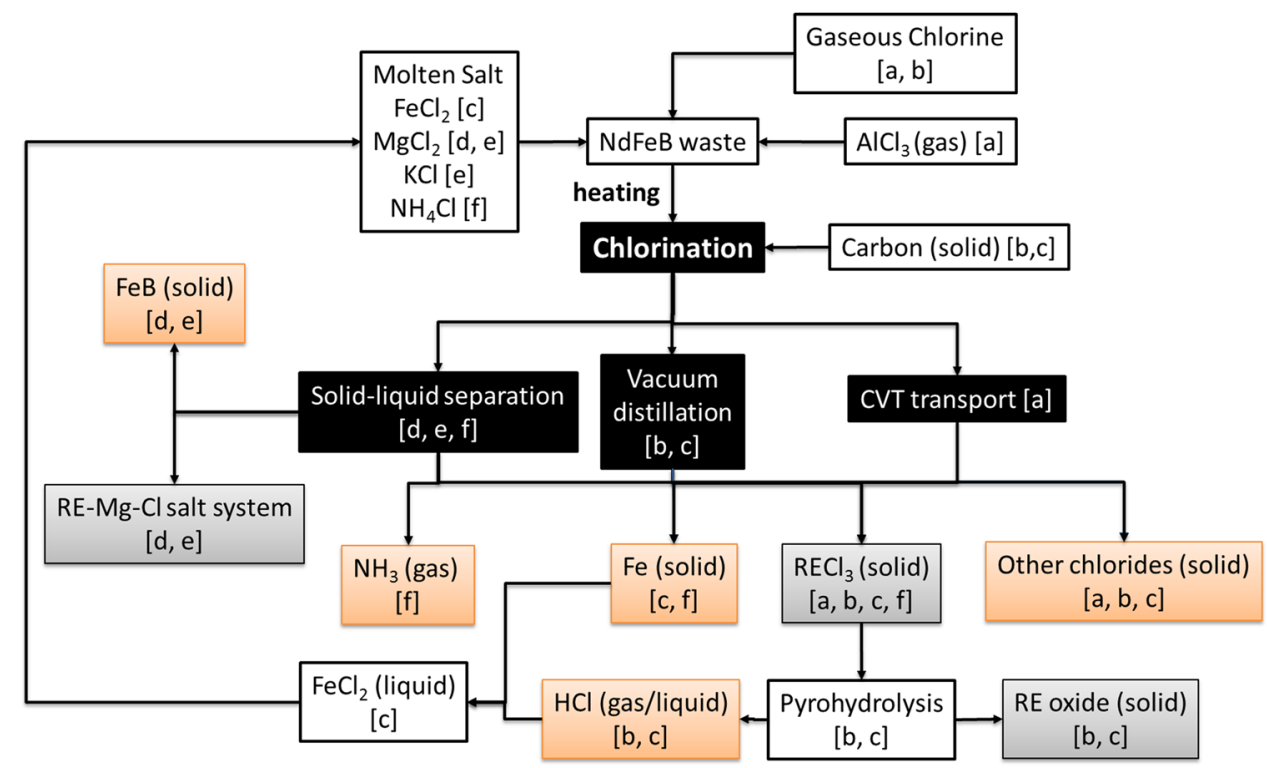


Table 4 Comparison of chlorine gas consumption

\begin{tabular}{llll}
\hline Reference & Sample used & Chlorine gas rate $(\mathrm{ml} / \mathrm{min})$ & Reaction time \\
\hline Murase et al. $[29,30]$ & $1 \mathrm{~g}$ dried $\mathrm{Nd}_{2} \mathrm{Fe}_{14} \mathrm{~B}$ sludge & 5 & $6 \mathrm{~h}$ \\
Mochizuki et al. $[55,56]$ & $0.2 \mathrm{~g}$ oxidized $\mathrm{Nd}_{2} \mathrm{Fe}_{14} \mathrm{~B}$ scrap & 100 & $30-120 \mathrm{~min}$ \\
\hline
\end{tabular}

$\mathrm{B}<\mathrm{Nd}<\mathrm{Dy}<\mathrm{Zr}<\mathrm{Fe}<\mathrm{Cu}=\mathrm{Co}[55,56]$. Most, if not all, elements changed to stable forms that were less affected by chlorination with increase in the oxidation treatment temperature. The rate of chlorination of Fe decreased with an increase in the oxidation treatment temperature, due to the form of Fe present in the oxidized sample. They suggested that $\mathrm{FeNdO}_{3}$ formed at higher temperature (refer to "NdFeB Oxidation Thermodynamics, Kinetic and Mechanism" section) might be more stable than $\mathrm{Fe}_{2} \mathrm{O}_{3}$ during chlorination. This may also be true for boron since $\mathrm{B}_{2} \mathrm{O}_{3}$ is more stable than $\mathrm{BCl}_{3}$. The stable oxides that formed can be reduced by adding carbon to the reaction. It was found that selective separation of RE elements from oxidized samples with carbon addition was possible by holding the samples at $1173 \mathrm{~K}$, because the $\mathrm{RE}$ elements remain in the carbochlorination residue. $\mathrm{Nd}$ oxide then can be produced from modification of RE chloride and $\mathrm{NdOCl}$ by steam treatment of carbochlorination residue at $1273 \mathrm{~K}$.

\section{Extraction of RE from NdFeB Magnet Using Molten Salt}

REEs in magnets can be selectively oxidized (through chlorination or iodization) then leached into a molten salt [33]. The disadvantages of molten salt leaching are the need to heat a large mass to a high temperature and the difficulty of separating the leach solvent from the gangue to leave a residue fit for disposal. Because the reaction product is a RE halide, it is possible to separate REs from the extraction medium using differences in vapor pressure (Fig. 13), resulting in the simultaneous separation of REEs. Uda et al. [31, 32] studied such a selective chlorination flowsheet with molten $\mathrm{FeCl}_{2}$ combined with distillation (Table 2 Route No. 2). Molten $\mathrm{FeCl}_{2}$ (m.p. $950 \mathrm{~K}$, b.p. $1297 \mathrm{~K}$ ) not only acts as the reaction medium for chlorination but also keeps the activity of iron in the neodymium magnet sludge at unity or close to unity, thereby increasing chlorination selectivity. Carbon is added to convert $\mathrm{NdOCl}$ to $\mathrm{NdCl}_{3}$ in the presence of $\mathrm{FeCl}_{2}$ (Eq. 9) at $1273 \mathrm{~K}$. The RE chlorides condense in the higher-temperature (853$1123 \mathrm{~K}$ ) collector, and the $\mathrm{FeCl}_{2}, \mathrm{BCl}_{3}$, and $\mathrm{AlCl}_{3}$ deposit in the lower-temperature (413-813 K) collector. The residue consists of large amounts of $\alpha$-Fe, graphite, and $\mathrm{Fe}_{3} \mathrm{C}$ and a small amount of $\mathrm{NdOCl}$.

$$
\begin{aligned}
& \mathrm{NdOCl}(\mathrm{s})+\mathrm{FeCl}_{2}(\mathrm{l})+\mathrm{C}(\mathrm{s}) \\
& \quad \rightarrow \mathrm{CO}(\mathrm{g})+\mathrm{NdCl}_{3}(\mathrm{l})+\mathrm{Fe}(\mathrm{s})
\end{aligned}
$$

In a second step, the anhydrous RE trichlorides are hydrated and transformed into the corresponding RE oxides by pyrohydrolysis. $\mathrm{HCl}$ is released and can be used for the conversion of $\mathrm{Fe}$ to $\mathrm{FeCl}_{2}$. The main advantage of this flowsheet is that only water and carbon are consumed. Moreover, the by-products (carbon dioxide, hydrogen gas, and iron alloy) have low environmental loads. The REOs produced can be reduced by electrolysis in molten fluoride.

Based on their findings of $\mathrm{Mg}$ affinity with REEs in liquid metal extraction [25], Shirayama and Okabe [33] studied recycling neodymium magnet scrap using molten $\mathrm{MgCl}_{2}$. REEs in $\mathrm{NdFeB}$ scrap selectively reacted with $\mathrm{MgCl}_{2}$ to form $\mathrm{RECl}_{3}$, leaving solid $\mathrm{Fe}-\mathrm{B}$ alloy and impurity elements behind. Approximately $80 \%$ of $\mathrm{Nd}$ and Dy could be efficiently extracted as chloride following $12 \mathrm{~h}$ of reaction. The technique was modified by Hua et al. [70] by using the binary system $\mathrm{MgCl}_{2}-\mathrm{KCl}$, which exhibits a lower melting point and viscosity, as well as lower volatility compared with pure $\mathrm{MgCl}_{2}$.

Itoh et al. [34] investigated a process based on the same approach but using $\mathrm{NH}_{4} \mathrm{Cl}$ as the chlorination agent. $\mathrm{Nd}$ and $\mathrm{Nd}_{2} \mathrm{O}_{3}$ were easily chlorinated to form $\mathrm{NdCl}_{3}$ with high conversion rate. Both $\alpha-\mathrm{Fe}$ and $\mathrm{Fe}_{2} \mathrm{O}_{3}$ were chlorinated to generate $\mathrm{FeCl}_{2}$, but with conversion rates of around 30 and $90 \%$, respectively, due to the higher reactivity of $\mathrm{Fe}_{2} \mathrm{O}_{3}$ with $\mathrm{NH}_{4} \mathrm{Cl}$. The $\mathrm{FeCl}_{2}$ further reacted with $\mathrm{Nd}$ metal to form metallic $\mathrm{Fe}$ and $\mathrm{NdCl}_{3}$. The resultant $\mathrm{RE}$ chlorides could be consequently recovered by leaching the reacted solids with water. Up to $90 \%$ of the REEs were recovered from low oxygen REPM powder scrap using this technique. The advantage of this approach is that the resin compacts prepared from the $\alpha$-Fe powder by-product possess high coercivity of around $0.04 \mathrm{~T}$ with a saturation magnetization value of $140 \mathrm{emu} / \mathrm{g}$ and provide good electromagnetic wave absorption ability in the SHF band. This approach could be appropriate for treating large volumes of scrap such that all elements can be reused as a starting source or a functional material.

\section{Liquid Metal Extraction (LME)}

Liquid metal extraction (LME) is similar in principle to conventional low temperature liquid-liquid solvent extraction. It consists of selective dissolution of the RE alloy by a liquid alloy system in which the REs and transition metals distribute between two immiscible liquid 
Table 5 Calculated diffusion coefficients for $\mathrm{Nd}$ in liquid $\mathrm{Mg}$ [40, 43]

\begin{tabular}{lll}
\hline Temperature $(\mathrm{K})$ & Diffusion coefficient, D $\left(\mathrm{cm}^{2} / \mathrm{s}\right)$ & References \\
\hline 973 & $4.61 \times 10^{-8}$ & {$[40]$} \\
993 & $1.38 \times 10^{-8}$ & {$[43]$} \\
1023 & $1.66 \times 10^{-8}$ & {$[43]$} \\
1073 & $2.89 \times 10^{-8}$ & {$[43]$} \\
\hline
\end{tabular}

metal phases [2]. Xu et al. [40] introduced the possibility of using $\mathrm{Mg}$ melt to adsorb Nd from REPM scraps. The extraction was suggested based on earlier findings that $\mathrm{Nd}$ has a high affinity with $\mathrm{Mg}$ ( $\mathrm{Nd}$ solubility in liquid $\mathrm{Mg}$ is around 65 at. $\%$ at $1073 \mathrm{~K}$ ) and that $\mathrm{Mg}$ and $\mathrm{Fe}$ are essentially immiscible (Fe solubility less than 0.035 at. $\%$ at $1073 \mathrm{~K}$ in molten $\mathrm{Mg}$ ). $\mathrm{Xu}$ et al. [40] studied the diffusion behavior of $\mathrm{Nd}$ from $\mathrm{NdFeB}$ into $\mathrm{Mg}$ melt and found that the diffusion proceeds rapidly at temperatures above $973 \mathrm{~K}$, enriching the $\mathrm{Mg}$ with $\mathrm{Nd}$. Chae et al. [43] further investigated this diffusion behavior and calculated the diffusion coefficients at $1000-1073 \mathrm{~K}$. Similar to $\mathrm{Xu}$ et al.'s [40] findings, observation of the microstructure showed that the high affinity of $\mathrm{Nd}$ for $\mathrm{Mg}$ causes $\mathrm{Nd}$ to rapidly diffuse out of the solid magnet scrap into the liquid. The solidified $\mathrm{Mg}$ consists of dendrite-like equiaxial $\mathrm{Mg}$ grains with Nd-rich phases $\left(\alpha-\mathrm{Mg}+\mathrm{Nd}\right.$ and $\left.\mathrm{Mg}_{12} \mathrm{Nd}\right)$ present at the grain boundaries. They also found that the diffusion distance increased linearly with increasing temperatures and maintaining times. Values of the diffusion coefficient $(D)$ of $\mathrm{Nd}$ in liquid $\mathrm{Mg}$ estimated by $\mathrm{Xu}$ et al. [40] and Chae et al. [43], based on the mass transport analysis summarized in Table 5.

$\mathrm{Na}$ et al. [74] investigated the effects of $\mathrm{NdFeB}$ magnet scrap size on extraction behavior and found that the amount of $\mathrm{Nd}$ extracted increased with increasing holding time and decreasing scrap size at $1073 \mathrm{~K}$ for $10-50 \mathrm{~min}$. They found that reducing scarp size for less than $5 \mathrm{~mm}$ increased oxidation and reduced extracted Nd. The maximum contents of $\mathrm{Nd}$ in $\mathrm{Mg}$ were about 24.2 mass \% for conditions of the $5 \mathrm{~mm}$ sized scrap heated for $50 \mathrm{~min}$.

Takeda and Okabe et al. [41, 42, 44, 75] investigated a continuous extraction process using liquid magnesium with two interrelated steps similar in principal to the continuous solid-liquid extraction process with a Soxhlet extractor in organic chemistry [2]. The process took advantage of the high vapor pressure of magnesium $(0.73 \mathrm{~atm}$ at $1300 \mathrm{~K})$ and the very low vapor pressure of neodymium (less than $10^{-6} \mathrm{~atm}$ at $\left.1300 \mathrm{~K}\right)$. Molten magnesium circulated due to the temperature difference in inside the reaction vessel as seen in Fig. 14. As part of the investigation, Takeda et al. [75] also determined $\mathrm{Fe}-\mathrm{Mg}-\mathrm{Nd}$ phase diagram at $1076 \mathrm{~K}$. In the process investigated, $\mathrm{Mg}$ evaporated from tantalum

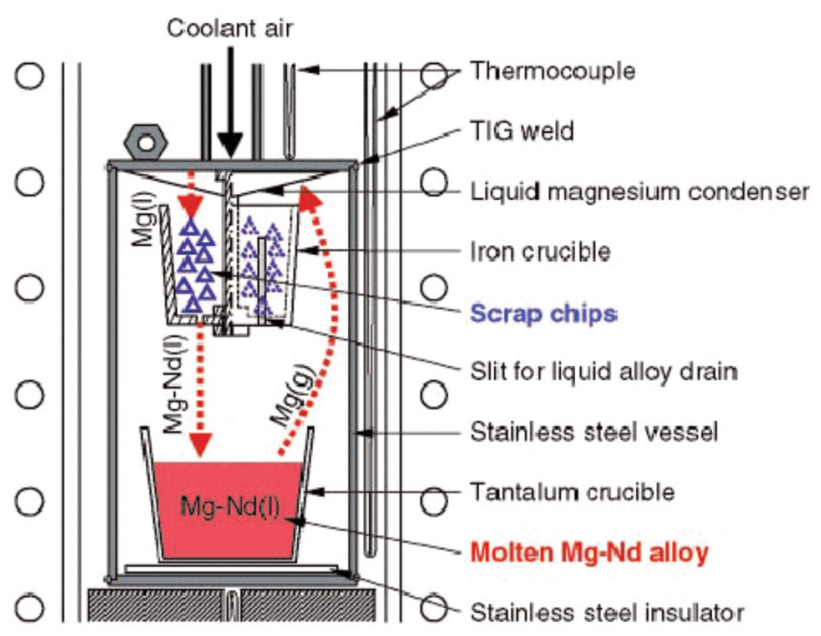

Fig. 14 Schematic of Takeda et al.'s [41, 42] apparatus for extracting neodymium from scrap alloys using magnesium circulation

crucibles at the bottom of the reactor (high-temperature zone) at $1073-1273 \mathrm{~K}$. The $\mathrm{Mg}$ then condensed at the top of the reactor, with temperature adjusted to 1002-1207 K by coolant gas. The condensed liquid $\mathrm{Mg}$ then leached the $\mathrm{Nd}$ from scrap in an iron crucible. The $\mathrm{Mg}-\mathrm{Nd}$ liquid alloy thus formed was drained through a slit in the iron crucible into the tantalum crucible. The liquid $\mathrm{Mg}-\mathrm{Nd}$ alloy can then be separated from the iron-boron particles. $\mathrm{Nd}$ metal can be recovered from the alloy by vacuum distillation of $\mathrm{Mg}$. Nd metal with up to $97.7 \%$ purity could be recovered directly from magnet scrap in under $24-72 \mathrm{~h}$ reaction time. This process has some significant advantages over aqueous processing technologies because the liquid metal solvent can be recycled and the waste streams are kept to a minimum [2]. The authors also proposed the use of magnesium alloy scrap instead of pure magnesium for the extraction process, for economic reason. These advantages should be weighed against the drawbacks of high-temperature liquid metal processing and energy costs of the magnesium distillation if pure RE alloys are the ultimate target. The main disadvantages of this process are that (1) it cannot be applied to (partly) oxidized REPM scrap, and (2) the process is relatively slow.

Sun et al. [76] proposed a different approach. A magnesium melt was stirred for 15 min along with the slow addition of REPM powders then held for a time to allow the heavy Fe-rich compounds to settle and also provide sufficient time for the diffusion of $\mathrm{Nd}$ from the magnet to the magnesium melt. After a specified holding time about $2 / 3$ of the melt (top melt) was poured into a preheated permanent metallic mold. This is called the first recycle. In the second-recycle the bottom melt, which was rich in $\mathrm{Fe}$ compounds and inclusions, was further treated with more pure $\mathrm{Mg}$ and then poured into the mold as well. The 
residual melt at the very bottom was slag-like and was poured out to form a bulk $\mathrm{Fe}$ waste, They found that 30 min holding time was sufficient for the compounds to settle to the bottom of the crucible due to the higher density $\left(\sim 7.9 \mathrm{~g} / \mathrm{cm}^{3}\right)$ than the $\mathrm{Mg}\left(\sim 1.6 \mathrm{~g} / \mathrm{cm}^{3}\right)$ melt. The recovery of $\mathrm{Nd}$ varied with the temperature and $\mathrm{Nd}$ addition ratio (in the form of $\mathrm{NdFeB}$ magnet). The optimal temperature was $1000 \mathrm{~K}$, at which temperature no $\mathrm{Nd}_{2} \mathrm{O}_{3}$ formed. The process is promising because the product can be used as raw material for $\mathrm{Mg}$ alloy casting, with acceptable impurity levels of $\mathrm{Fe}$ and $\mathrm{B}$, instead of using pure $\mathrm{Nd}$ from primary production. In another approach, also introduced by Takeda et al. [44], silver (melting point $1235 \mathrm{~K}$ ) was substituted for Mg for the direct extraction of neodymium from NdFeB. Silver dissolves neodymium, but not iron or boron. The neodymium can be separated from the $\mathrm{Ag}-\mathrm{Nd}$ alloy by oxidation to $\mathrm{Nd}_{2} \mathrm{O}_{3}$, which is insoluble in molten silver. The process is an interesting option for an industrial approach because of the recyclability of the silver. However, the end product is a rare-earth oxide, as opposed to a rare-earth metal for the magnesium solvent method [2].

\section{Recycling via Hydrogenation}

Previous researchers $[13,45]$ proposed a technology which uses hydrogen at atmospheric pressure to process sintered REE magnets to produce a demagnetized hydrided alloy powder of NdFeB. Hydrogen decrepitation (HD)/hydrogenation disproportionation desorption recombination (HDDR) is a process used in manufacturing REPM and carried out as pretreatment before green body sintering. During hydrogenation, the Nd-rich grain boundary phase in $\mathrm{NdFeB}$ magnets initially absorbs hydrogen forming $\mathrm{Nd}$ hydride: [49].

$$
\begin{aligned}
\text { Disproportionation } & \rightarrow \mathrm{Nd}_{2} \mathrm{Fe}_{14} \mathrm{~B}+2 x \mathrm{H}_{2} \\
& \leftrightarrow 2 \mathrm{NdH}_{2 x}+12 \mathrm{Fe}+\mathrm{Fe}_{2} \mathrm{~B} \\
& \leftarrow \text { Recombination }
\end{aligned}
$$

This is an exothermic reaction with an associated $5 \%$ volume expansion due to the expansion of the crystal lattice with the formation of the hydrides. The differential expansion between the surface and the bulk causes the surface material to break away into coarse granules/powder. However, as the temperature increases these hydrides become unstable and the material disproportionates to form $\alpha-\mathrm{Fe}, \mathrm{F}_{2} \mathrm{~B}$, and $\mathrm{NdH}_{2}$. The powder can be used in the production of resin bonded magnets either by degassing the hydrogen under vacuum and mixing with an appropriate binder or by further processing of the powder by the HDDR route. This process has been further developed [46, 47, 49, 50] to increase the recycling efficiency. Périgo et al. [77]

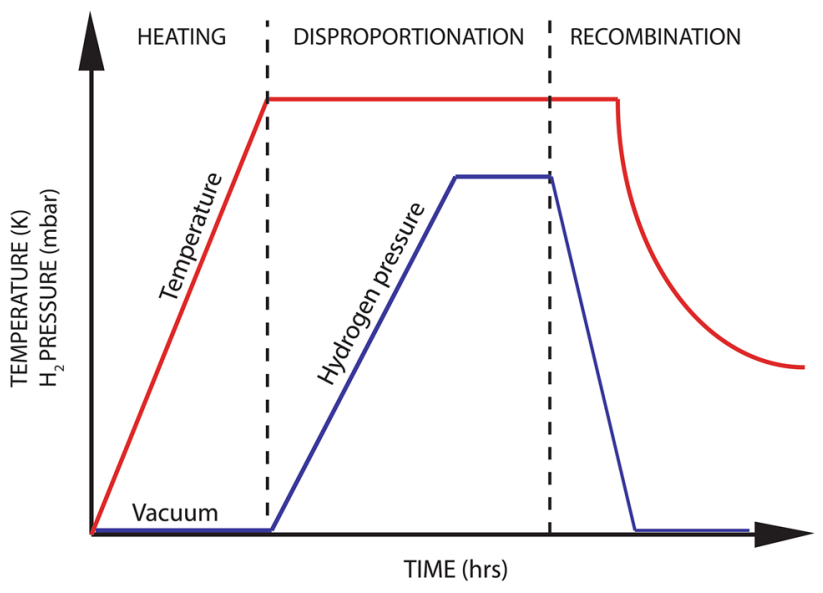

Fig. 15 Schematic showing the d-HDDR processing conditions [49]

employed the HDDR process to recycle N42 sintered magnets to make isotropic powders and investigated the effect of recombination temperature and $\mathrm{H}_{2}$ pressure on the magnetic properties of recycled magnets. Li et al. [46, 78, 79] studied the influence of particle distribution and hydrogenation conditions, and found that (1) the oxygen content decreases rapidly as particle size distribution increases and (2) higher $\mathrm{H}_{2}$ pressure during hydrogenation results in decreasing oxygen content. Both Sheridan et al. [80] and Gutfleisch et al. [81] used a higher processing pressure during disproportionation and avoided subsequent oxygen exposure by performing both the v-HD and s-DR processes in the same furnace. They showed that anisotropic resin-bonded magnets could be produced by recycling $\mathrm{Nd}-\mathrm{Fe}-\mathrm{B}$ sintered magnets using a combined d-HDDR (dynamic HDDR) route. Figure 15 shows qualitatively the processing conditions and hydrogen pressure evolution during the combined d-HDDR process. Sheridan et al. [49] found that the best magnetic properties were achieved by processing at $1153 \mathrm{~K}$, producing a sample with a magnetic remanence of $1.08(70.02) \mathrm{T}$ and an intrinsic coercivity of around $840 \mathrm{kA} / \mathrm{m}$. However, magnetic properties of the lower Dy content magnet were affected significantly by the processing temperature with a peak in properties observed at $1153 \mathrm{~K}$.

This process has the advantage of reducing the REPM lifecycle but is not applicable to RE recovery. The drawbacks are the reduction in magnetic properties of the recycled product and its inability to treat highly oxidized waste. Separation efficiencies of around $95 \%$ have been reported on small scale trials. Further physical processing techniques can then be applied which reduce the Ni content to $<325 \mathrm{ppm}$. After hydrogen processing, the scrap is tumbled in a porous drum to liberate the hydrided $\mathrm{NdFeB}$ powder and $\mathrm{Ni}$ flakes. The success of this technology depends on sufficient access for hydrogen and an exit route for the hydrided $\mathrm{NdFeB}$ powder. 


\section{Electrolysis Using Molten Salt and Ionic Liquids}

The separation and production of RE metal using electrolysis was first studied by Kobayashi et al. [52, 80, 81] using molten fluoride $\left(\mathrm{LiF}-\mathrm{CaF}_{2}-\mathrm{NdF}_{3}\right)$ and an iron group (RE-IG) alloy diaphragm. Waste containing RE was used as the anode, and REs were anodically dissolved by molten salt electrolysis as shown in Fig. 16. Combinations of different salts $(\mathrm{LiCl}-\mathrm{KCl}$ and $\mathrm{NaCl}-\mathrm{KCl})$, compositions, and temperatures (from 873 to $1123 \mathrm{~K}$ ) were investigated by Martinez et al. [82]. The application was further developed by Yasuda et al. [54] to prepare RE-Ni alloy from magnet scrap using molten $\mathrm{NaCl}-\mathrm{KCl}-\mathrm{RECl}_{3}$ as electrolyte. Konishi et al. [83, 84] performed anodic potentiostatic electrolysis at 1.70 and $2.20 \mathrm{~V}$ for $12 \mathrm{~h}$ using $\mathrm{Nd}-\mathrm{Fe}-\mathrm{B}$ magnet as electrodes. The RE ions were reduced on the anode compartment side of the alloy diaphragm. RE ions reduced on the bipolar diaphragm react with the bipolar electrode, form RE alloys, and became diffused inside the diaphragm. The diffusing RE elements in the electrode were anodically redissolved on the surface of the cathode compartment side of the diaphragm. Finally, the REs precipitated as highly pure metal when the RE ions on the cathode compartment side were reduced on the cathode via molten salt. From EDX analysis of the cross section of a sample obtained at $1.70 \mathrm{~V}$, it was found that RE in the outer layer was selectively dissolved but RE in the inner layer remained undissolved. Martinez et al. [82] found that LiCl-based melt offered a better option electrochemically (larger potential separation from the Nd reduction potential) than NaCl-based electrolyte. However, under-potential deposition (UPD) of lithium (i.e., deposition at activity lower than unity) on neodymium made it difficult to deposit $\mathrm{Nd}$ free of $\mathrm{Li}$. Li co-deposition could (to some extent) be avoided by increasing the activity of $\mathrm{Nd}$ ions in the electrolyte. Yasuda et al. [54] investigated the separation of $\mathrm{Nd}$, Dy, and Pr using the differences in formation potentials and formation rates of the RE-IG alloys employed as the diaphragm. They found that formation of the Dy-Ni alloy layer proceeded 10 times faster than that of $\mathrm{Nd}-\mathrm{Ni}$ and $\mathrm{Pr}-\mathrm{Ni}$ at the electrolysis potential range for effective separation, which was around $0.39-0.48 \mathrm{~V}$ (relative with respect to a $\mathrm{Na}^{+} / \mathrm{Na}^{-}$reference electrode). The process is advantageous because it allows the simultaneous extraction and separation of materials. It is, however, still under research and development as many issues need to be resolved before treating actual scrap. The existing limitation on the cell design and understanding of molten salt's behavior and optimal conditions are some of the aspects that still need to be further studied.

\section{Concluding Remarks}

Due to the increasing demand for REEs and their increasing application in green technology, recycling and recovering these elements from waste is a critical issue. High-temperature processing is one alternative that can be used to avoid large consumption of water and production of hazardous waste in the recovery process. A number of techniques are available for recovering REs from magnet waste by high-temperature processing, but all are still at the research stage, and currently none has been applied in a commercial scale in industry. More options in terms of recycling product are available compared to hydrometallurgical approach as both alloying metal and/or RE metal
Fig. 16 Schematic of the electrolytic process for separation and recovery of rareearth metals [80]

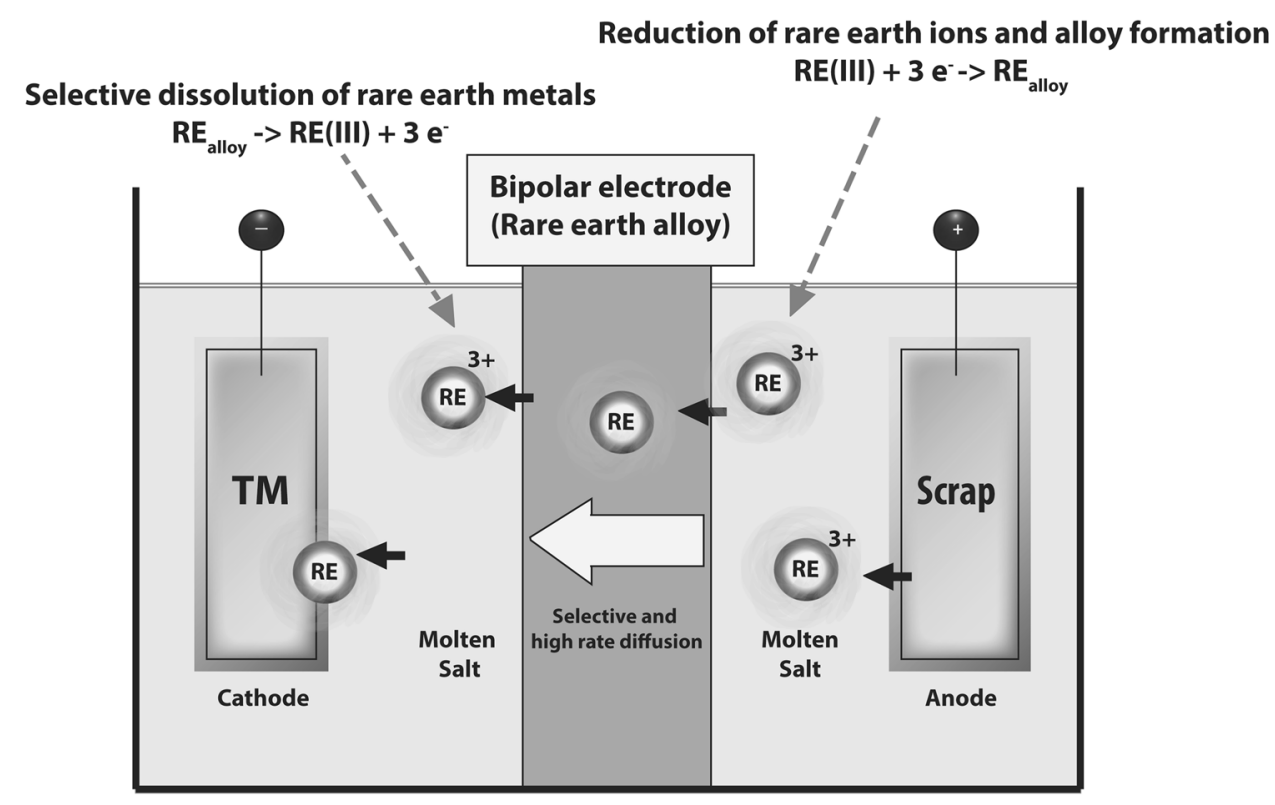


can be produced depending on which technique is used. Most of the available techniques are multistage in which at least two or three steps are required to recover the REEs from the waste. Although the future is promising for high-temperature recycling, there are evident barriers or challenges that need to be overcome including (i) the different mix of wastes produced; (ii) the effects of contaminants on the recycling process; (iii) optimization for mutual separation of REs (Nd, Dy, Pr); and (iv) feasibility (economics and lifecycle). It is also understandable that combinations of methods may be required to completely recover REs from magnetic waste. Thus, further fundamental study on the thermodynamics and kinetics behaviors of the magnets (including the behavior of each individual REE for mutual separation) during high-temperature processes is required to optimize the available techniques and to analyze the best option. It should be noted that it is also important to consider ways to integrate these techniques into primary processing and/ or wider e-waste processing.

\section{References}

1. Tanaka $M$ et al (2013) Chapter 255-Recycling of rare earths from scrap. In: Jean-Claude GB, Vitalij KP (eds) Handbook on the physics and chemistry of rare earths. Elsevier, Amsterdam, pp 159-211

2. Binnemans $\mathrm{K}$ et al (2013) Recycling of rare earths: a critical review. J Clean Prod 51:1-22

3. Takeda O, Okabe TH (2014) Current status on resource and recycling technology for rare earths. Metall Mater Trans E 1:160-173

4. Rombach E, Friedrich B (2014) Chapter 10-Recycling of rare metals. In: Worrell E, Reuter MA (eds) Handbook of recycling. Elsevier, Boston, pp 125-150

5. Ayres RU, Méndez GV, Peiró LT (2014) Chapter 4-Recycling rare metals. In: Worrell E, Reuter MA (eds) Handbook of recycling. Elsevier, Boston, pp 27-38

6. Zepf V (2013) Rare earth elements: a new approach to the nexus of supply, demand and use: exemplified along the use of neodymium in permanent magnets. Doctoral thesis, University of Augsburg, Germany

7. Golev A et al (2014) Rare earths supply chains: current status, constraints and opportunities. Resour Policy 41(1):52-59

8. Rademaker JH, Kleijn R, Yang Y (2013) Recycling as a strategy against rare earth element criticality: a systemic evaluation of the potential yield of NdFeB magnet recycling. Environ Sci Technol 47(18): 10129-10136

9. Asabe K et al (2001) Recycling of rare earth magnet scraps: part I carbon removal by high temperature oxidation. Mater Trans 42(12):2487-2491

10. Nakamoto $\mathrm{M}$ et al (2012) Extraction of rare earth elements as oxides from a neodymium magnetic sludge. Metall Mater Trans B 43(3):468-476

11. Saeki T et al (2014) Environment-friendly recycling process for rare earth metals in end-of-life electric products. Rare metal technology 2014. Wiley, Hoboken, NJ, pp 103-106

12. Minowa T (2008) Rare earth magnets: conservation of energy and the environment. Resour Geol 58(4):414-422
13. Zakotnik M, Harris IR, Williams AJ (2008) Possible methods of recycling $\mathrm{NdFeB}$-type sintered magnets using the $\mathrm{HD} /$ degassing process. J Alloy Compd 450(1-2):525-531

14. Bian Y et al (2015) Extraction of rare earth elements from permanent magnet scraps by $\mathrm{FeO}-\mathrm{B}_{2} \mathrm{O}_{3}$ flux treatment. J Sustain Metall 1:151-160

15. Sasaki TT et al (2015) Effect of carbon on the coercivity and microstructure in fine-grained $\mathrm{Nd}-\mathrm{Fe}-\mathrm{B}$ sintered magnet. Acta Mater 84:506-514

16. Van Ende M-A, Jung I-H (2013) Critical thermodynamic evaluation and optimization of the $\mathrm{Fe}-\mathrm{B}, \mathrm{Fe}-\mathrm{Nd}, \mathrm{B}-\mathrm{Nd}$ and $\mathrm{Nd}-\mathrm{Fe}-\mathrm{B}$ systems. J Alloy Compd 548:133-154

17. Matsuura $\mathrm{M}$ et al (2010) Influence of $\mathrm{Nd}$ Oxide phase on the coercivity of Nd-Fe-B thin films. Mater Trans 51(10):1901-1904

18. Belin-Ferré E (2008) Basics of thermodynamics and phase transitions in complex intermetallics. Book series on complex metallic alloys. World Scientific, Singapore

19. Nagai T, Shirai S, Maeda M (2011) Thermodynamic measurement of $\mathrm{Nd}-\mathrm{Fe}$ system by double Knudsen cell mass spectrometry. Thermochim Acta 516(1-2):8-12

20. Hallemans B, Wollants P, Roos JR (1995) Thermodynamic assessment of the Fe-Nd-B phase diagram. J Phase Equilib 16(2):137-149

21. Zhang W, Liu G, Han K (1992) The Fe-Nd (Iron-Neodymium) system. J Phase Equilib 13(6):645-648

22. Okamoto H (1997) Fe-Nd (iron-neodymium). J Phase Equilib 18(1):106

23. Marazza R, Riani P, Cacciamani G (2008) Critical assessment of iron binary systems with light rare earths $\mathrm{La}, \mathrm{Ce}, \mathrm{Pr}$, and $\mathrm{Nd}$. Inorg Chim Acta 361(14-15):3800-3806

24. Franke P, Neuschütz D (2005) Fe-Nd. In: Franke P, Neuschütz D (eds) Binary systems. Part 3: binary systems from Cs-K to Mg-Zr. Springer, Berlin, pp 1-3

25. Nagai T, Shirai S, Maeda M (2013) Thermodynamic measurement of Dy $+\mathrm{Fe}$ binary system by double Knudsen cell mass spectrometry. J Chem Thermodyn 65:78-82

26. Hussain A et al (2013) Critical thermodynamic evaluation and optimization of the $\mathrm{Co}-\mathrm{Nd}, \mathrm{Cu}-\mathrm{Nd}$ and $\mathrm{Nd}-\mathrm{Ni}$ systems. Calphad 41:26-41

27. Feng $\mathrm{H}$ et al (2014) Experimental investigation of the $\mathrm{Al}-\mathrm{Fe}-\mathrm{Nd}$ system at $773 \mathrm{~K}$. J Phase Equilib Diffus 35(1):86-92

28. Takeda O, Nakano K, Sato Y (2014) Recycling of rare earth magnet waste by removing rare earth oxide with molten fluoride. Mater Trans 55(2):334-341

29. Murase K, Machida K-I, Adachi G-Y (1995) Recovery of rare metals from scrap of rare earth intermetallic material by chemical vapour transport. J Alloy Compd 217(2):218-225

30. Murase K et al (1995) Mutual separation of mixed praseodymium and neodymium oxides via metal halide gaseous complexes. Ind Eng Chem Res 34(11):3963-3969

31. Uda TKTM (2000) Technique for enhanced rare earth separation. Science 289(5488):2326-2329

32. Uda $\mathrm{T}$ (2002) Recovery of rare earths from magnet sludge by $\mathrm{FeCl}_{2}$. Mater Trans 43(1):55-62

33. Shirayama S, Okabe TH (2009) Selective extraction of Nd and Dy from rare earth magnet scrap into molten salt. In: The minerals, metals and materials society-3rd international conference on processing materials for properties (2008), PMP III Wiley, Hoboken, NJ

34. Itoh M, Miura K, Machida K-I (2009) Novel rare earth recovery process on $\mathrm{Nd}-\mathrm{Fe}-\mathrm{B}$ magnet scrap by selective chlorination using $\mathrm{NH}_{4}$ Cl. J Alloy Compd 477(1-2):484-487

35. Saguchi A et al (2002) Recycling of rare earth magnet scraps Part III carbon removal from $\mathrm{Nd}$ magnet grinding sludge under vacuum heating. Mater Trans 43(2):256-260

36. Saguchi A et al (2006) Recycling of rare earth magnet scraps: carbon and oxygen removal from Nd magnet scraps. J Alloy Compd 408-412:1377-1381 
37. Suzuki RO et al (2001) Recycling of rare earth magnet scraps: part II oxygen removal by calcium. Mater Trans 42(12):2492-2498

38. Saito $\mathrm{T}$ et al (2003) The extraction of $\mathrm{Nd}$ from waste $\mathrm{Nd}-\mathrm{Fe}-\mathrm{B}$ alloys by the glass slag method. J Alloy Compd 353(1-2):189-193

39. Miura K, Itoh M, Machida K-I (2008) Extraction and recovery characteristics of $\mathrm{Fe}$ element from $\mathrm{Nd}-\mathrm{Fe}-\mathrm{B}$ sintered magnet powder scrap by carbonylation. J Alloy Compd 466(1-2):228-232

40. Xu Y, Chumbley LS, Laabs FC (2000) Liquid metal extraction of Nd from NdFeB magnet scrap. J Mater Res 15(11):2296-2304

41. Takeda O, Okabe TH, Umetsu Y (2006) Recovery of neodymium from a mixture of magnet scrap and other scrap. J Alloy Compd 408-412:387-390

42. Okabe TH et al (2003) Direct extraction and recovery of neodymium metal from magnet scrap. Mater Trans 44(4):798-801

43. Chae $\mathrm{HJ}$ et al (2014) Experimental investigation of diffusion behavior between molten $\mathrm{Mg}$ and $\mathrm{Nd}-\mathrm{Fe}-\mathrm{B}$ magnets. J Alloys Compd 586 Supplement 1:S143-S149

44. Takeda O, Okabe TH, Umetsu Y (2004) Phase equilibrium of the system $\mathrm{Ag}-\mathrm{Fe}-\mathrm{Nd}$, and $\mathrm{Nd}$ extraction from magnet scraps using molten silver. J Alloy Compd 379(1-2):305-313

45. Zakotnik M, Harris IR, Williams AJ (2009) Multiple recycling of NdFeB-type sintered magnets. J Alloy Compd 469(1-2):314-321

46. Li C et al (2015) Recycling of scrap sintered Nd-Fe-B magnets as anisotropic bonded magnets via hydrogen decrepitation process. J Mater Cycles Waste Manag 17(3):547-552

47. Fredericci $\mathrm{C}$ et al (2014) Nd-enriched particles prepared from $\mathrm{NdFeB}$ magnets: a potential separation route. J Alloy Compd 615:410-414

48. Li C et al (2014) Waste Nd-Fe-B sintered magnet recycling by doping with rare earth rich alloys. IEEE Trans Magnet 50(12):1-3

49. Sheridan RS et al (2014) Improved HDDR processing route for production of anisotropic powder from sintered NdFeB type magnets. J Magn Magn Mater 350:114-118

50. Eisch OG et al (2013) Recycling used ND-FE-B sintered magnets via a hydrogen-based route to produce anisotropic, resin bonded magnets. Adv Energy Mater 3(2):151-155

51. Terada T, Onishi H, Kawakami T (2001) New solvolysis and its application to epoxy resin and bonded magnets. J Jpn Inst Met 65(7):627-634

52. Kobayashi S et al (2012) Electrochemical formation of Dy-Ni alloys in molten $\mathrm{LiF}-\mathrm{CaF}_{2}-\mathrm{DyF}_{3}$. J Electrochem Soc 159(12):E193-E197

53. Nohira $\mathrm{T}$ et al (2013) Electrochemical formation of $\mathrm{RE}-\mathrm{Ni}$ $(\mathrm{RE}=\mathrm{Pr}, \mathrm{Nd}, \mathrm{Dy})$ alloys in molten halides. ECS Trans 50(11):473-482

54. Yasuda $\mathrm{K}$ et al (2014) Selective formation of rare earth-nickel alloys via electrochemical reactions in $\mathrm{NaCl}-\mathrm{KCl}$ molten salt. ECS Trans 64(4):601-607

55. Mochizuki Y, Tsubouchi N, Sugawara K (2013) Selective recovery of rare earth elements from Dy containing $\mathrm{NdFeB}$ magnets by chlorination. ACS Sustain Chem Eng 1(6):655-662

56. Mochizuki Y, Mori H, Sugawara K (2011) Recovery of rare earth from Nd-Fe-B magnets by chlorination. Kagaku Kogaku Ronbunshu 37(1):70-77

57. Li Y et al (2003) The oxidation of NdFeB magnets. Oxid Met 59(1-2):167-182

58. Jacobson J, Kim A (1987) Oxidation behavior of Nd-Fe-B magnets. J Appl Phys 61(8):3763-3765

59. Le Breton JM, Teillet J (1990) Oxidation of (Nd, Dy)FeB permanent magnets investigated by $57 \mathrm{Fe}$ Mossbauer spectroscopy. IEEE Trans Magn 26(5):2652-2654

60. Dickens ED, Mazany AM (1990) The corrosion and oxidation of Nd-Fe-B magnets. J Appl Phys 67(9):4613-4615

61. Woodcock TG et al (2012) Understanding the microstructure and coercivity of high performance NdFeB-based magnets. Scr Mater 67(6):536-541
62. Sepehri-Amin $\mathrm{H}$ et al (2012) Grain boundary and interface chemistry of an $\mathrm{Nd}-\mathrm{Fe}-\mathrm{B}$-based sintered magnet. Acta Mater 60(3):819-830

63. Deshan L et al (2009) Grain boundary phase formation and magnetic properties of $\mathrm{NdFeB} / \mathrm{Nd}$ multilayered films. Jpn J Appl Phys 48(3R):033002

64. Liu WQ et al (2010) Oxidation kinetics of Nd-Fe-B permanent magnets prepared by spark plasma sintering. Corrosion 66(5):0550041-0550045

65. Skulj I, Evans HE, Harris IR (2008) Oxidation of NdFeB-type magnets modified with additions of Co, Dy, $\mathrm{Zr}$ and V. J Mater Sci 43(4):1324-1333

66. Steyaert S, Le Breton JM, Harris IR (1997) Microstructural investigation of oxidized Nd-Fe-B powders: influence of particle size on the oxidation behaviour. J Magn Magn Mater 176(2-3):297-306

67. Parida SC et al (2002) Thermodynamic studies on NdFeO3(s). J Solid State Chem 164(1):34-41

68. Saito T, Sato H, Motegi T (2006) Recovery of rare earths from sludges containing rare-earth elements. J Alloy Compd 425(1-2): 145-147

69. Adachi GY et al (1991) Rare earth separation using chemical vapor transport with $\mathrm{LnCl}_{3} \mathrm{AlCl}_{3}$ gas phase complexes. J Less Common Met 169(1):L1-L4

70. Hua $Z$ et al (2014) Selective extraction of rare earth elements from NdFeB scrap by molten chlorides. ACS Sustain Chem Eng 2(11):2536-2543

71. Kanari N et al (2009) An overview study of chlorination reactions applied to the primary extraction and recycling of metals and to the synthesis of new reagents. Thermochim Acta 495(1-2):42-50

72. Bosco MV, Fouga GG, Bohé AE (2012) Kinetic study of neodymium oxide chlorination with gaseous chlorine. Thermochim Acta 540:98-106

73. Anderson A, Mishra B (2015) Investigation of the carbochlorination process for conversion of cerium and neodymium oxides into their chlorides. J Sustain Metall 1(3):189-198

74. Na HW et al (2014) Effect of scrap size on extraction of neodymium from $\mathrm{Nd}-\mathrm{Fe}-\mathrm{B}$ magnet scrap by liquid metal extraction. Curr Nanosci 10(1):128-130

75. Takeda O, Okabe TH, Umetsu Y (2005) Phase equilibria of the system $\mathrm{Fe}-\mathrm{Mg}-\mathrm{Nd}$ at $1076 \mathrm{~K}$. J Alloy Compd 392(1-2):206-213

76. Sun $\mathrm{M}$ et al (2015) On the production of $\mathrm{Mg}-\mathrm{Nd}$ master alloy from NdFeB magnet scraps. J Mater Process Technol 218:57-61

77. Périgo EA et al (2012) Properties of hydrogenation-disproportionation-desorption-recombination $\mathrm{NdFeB}$ powders prepared from recycled sintered magnets. J Appl Phys 111(7):07A725-07A725-3

78. Li X et al (2015) Regeneration of waste sintered Nd-Fe-B magnets to fabricate anisotropic bonded magnets. J Rare Earths 33(7):736-739

79. Li XT et al (2015) Large batch recycling of waste $\mathrm{Nd}-\mathrm{Fe}-\mathrm{B}$ magnets to manufacture sintered magnets with improved magnetic properties. J Alloy Compd 649:656-660

80. Sheridan RS et al (2012) Anisotropic powder from sintered $\mathrm{NdFeB}$ magnets by the HDDR processing route. J Magn Magn Mater 324(1):63-67

81. Gutfleisch O et al (2013) Recycling used Nd-Fe-B sintered magnets via a hydrogen-based route to produce anisotropic, resin bonded magnets. Adv Energy Mater 3(2):151-155

82. Martinez AM et al (2013) Extraction of rare earth metals from Nd-based scrap by electrolysis from molten salts. ECS Trans 50(11):453-461

83. Konishi $\mathrm{H}$ et al (2014) Separation of Dy from Nd-Fe-B magnet scraps using molten salt electrolysis. ECS Trans 64(4):593-600

84. Oishi $\mathrm{T}$ et al (2010) Separation and recovery of rare earth metals by molten salt electrolysis using alloy diaphragm. Kagaku Kogaku Ronbunshu 36(4):299-303 